\title{
Natural Biocidal Compounds of Plant Origin as Biodegradable Materials Modifiers
}

\author{
Alona Pawłowska ${ }^{1}$ (1) $\cdot$ Magdalena Stepczyńska ${ }^{1}$
}

Accepted: 15 October 2021 / Published online: 23 October 2021

(c) The Author(s) 2021

\begin{abstract}
The article presents a literature review of the plant origin natural compounds with biocidal properties. These compounds could be used as modifiers of biodegradable materials. Modification of polymer material is one of the basic steps in its manufacturing process. Biodegradable materials play a key role in the current development of materials engineering. Natural modifiers are non-toxic, environmentally friendly, and renewable. The substances contained in natural modifiers exhibit biocidal properties against bacteria and/or fungi. The article discusses polyphenols, selected phenols, naphthoquinones, triterpenoids, and phytoncides that are natural antibiotics. Due to the increasing demand for biodegradable materials and the protection of the natural environment against the negative effects of toxic substances, it is crucial to replace synthetic modifiers with plant ones. This work mentions industries where materials containing natural modifying additives could find potential applications. Moreover, the probable examples of the final products are presented. Additionally, the article points out the current world's pandemic state and the use of materials with biocidal properties considering the epidemiological conditions.
\end{abstract}

Keywords Biodegradable polymers $\cdot$ Natural origin modifiers $\cdot$ Biocidal additives $\cdot$ Polyphenols $\cdot$ Phytoncides

\section{Introduction}

Modification of polymer materials is carried out to give the desired characteristics to the final products. These features depend on the application. For example, the industry in which the polymer materials will be used or the function they will perform. Modification is the most common way to give unique features and improve selected parameters of finished goods made from polymer materials. The modification changes their properties and internal structure. One of the methods of changing the internal structure of materials is the insertion of modifying additives. In general, it is carried out during the production process. The aspiration to reduce the number of additives gave rise to the search for modifiers that would give more than one new feature to the biodegradable material. Due to the current epidemiological situation, the research of compounds with biocidal properties added to polymer materials is in more dynamic progress

Alona Pawłowska

alona.pawlowska@ukw.edu.pl

1 Department of Materials Engineering, Kazimierz Wielki University, J.K. Chodkiewicza 30 street, 85-064 Bydgoszcz, Poland than ever before. The biocidal properties of the material are understood as the capability to reduce the number of pathogenic microorganisms under defined conditions [1-4]. The increase of public awareness of environmental pollution, the constant growth of the number of post-consumer waste, and care for human health are observed nowadays. Thus additives should meet the modern criteria and conditions. First of all, they should be non-toxic to human health and the environment [5]. Polymer materials used in the medical, pharmaceutical, and packaging industries are in close contact with the human body or food [6,7]. The application of polymer materials in mentioned industries may depend on the substances they contain. The additives contained in the material cannot interact with other materials. All of the mentioned conditions concern both modifying additives and polymer matrices.

Biopolymers are the polymers that naturally occur in flora and fauna [8]. They cause no environmental pollution and are completely harmless for the inhabitants of the earth. Moreover, this kind of polymers is obtained from renewable resources which do not destroy our planet. The natural origin of this type of materials makes them biodegradable-susceptible to chemical processes that lead to the decomposition of biochemical substances. The decomposition is done by 
microorganisms [9]. The biopolymers are well suited for biocomposites (composites that are produced from renewable raw materials) manufacturing due to their biodegradability, no-toxicity, and natural origin.

Biocomposites are promising materials that may be implemented into everyday use. The processing of biocomposites with biopolymer matrix doped with natural-origin modifying additives is a promising field of biodegradable biocomposites. Biocomposites like this are the present development trend in polymer materials. The current literature state helps to create a classification of modifying additives of natural origin which contain organic substances.

This article presents already used modifiers and those having the potential to be used in the production of polymer materials that exhibit biocidal properties. The synthesis, properties, and application of natural modifiers of plant origin are discussed. The basic groups of polyphenols and selected compounds of natural origin such as some phenols, naphthoquinones, triterpenoids, or phytoncides are presented.

\section{Biopolymer Matrices}

Polymer might be called biopolymer if it is biobased (produced by the living organism) or/and biodegradable. They are divided into two groups. The first group of biopolymers (natural) is obtained from living organisms, while the second one (synthetic) is produced during the polymerization of selected compounds contained in renewable resources [10-12]. Moreover, the natural biopolymers group consists of two subgroups: polysaccharides and proteins, while the synthetic biopolymers group is divided into degradable and non-degradable biopolymers [10]. Most of the representatives of mentioned groups are used as materials for biocomposite matrices. Due to the current ecological threat resulted from residual plastic waste the creation of completely biodegradable composites is crucial. It is possible, however, every part of the composite should be biodegradable. Therefore, the application of natural plant modifiers in biocomposites is an excellent solution for environment-friendly materials.

\section{Chitosan}

Chitosan belongs to polysaccharides. This biopolymer is sourced from chitin-one of the most common polysaccharides in the world. It occurs in marine shellfish, insects, mushrooms, and yeast. The highest percentage content of chitin has been observed in shells and tails of crabs, shrimps, and lobsters. Hence, chitosan could be "recycled" from seafood waste. This method of chitosan extraction could improve current environmental conditions [13-15].
Chitosan is known as a semicrystalline polymer material with various types of crystal structures (polymorphism). It is a biodegradable, biocompatible, and renewable polymer material with antioxidant properties. Moreover, chitosan is non-toxic for humans and bioactive against selected microorganisms and viruses $[15,16]$. Material is soluble in acid solution and non-soluble in the majority of solvents. Its hydrophilic properties promote the ability to create films. However, the hydrophilicity of this material has its drawback: it leads to material swelling in water. Hence, material modification is advised. Furthermore, it is known that chitosan is susceptible to modification [17].

This biopolymer is used for environmental protection purposes (e.g. water purification) [17]. In the agricultural industry, chitosan is applied as a biostimulator that promotes plants growth and their defense mechanisms. As a seed coating material chitosan improves its germination rate [18]. Due to its biological activity, it is used in the food and food packing industries as a biopreservative that extends the shelf life of products [19, 20]. Material has potential application in the medical industry due to its unique (e.g. wound healing) properties. Chitosan could be applied as surgical sutures or in bones and dental prosthetics. According to the hydrating properties of the compound, it is could be used as a material for contact lenses [15, 21].

\section{Starch}

Starch is another natural polymer that belongs to polysaccharides [22]. It occurs in plant roots, tubers, and fruits. The main sources of starch are cereals and potatoes. Although it could be extracted from certain varieties of pea and lily [23, 24]. Starch consists of homopolymers-amylase and amylopectin. Amylase is soluble, while amylopectin is non-soluble $[8,22]$. Wet grinding, drying, and sieving are the main ways to obtain starch [24].

Energy storage is the main function performed by starch in various plants [25]. Starch is a hydrophilic biodegradable polymer that is non-soluble in cold water and soluble in diluted solutions of acids and bases. It is known that the mechanical treatment (milling) of starch improves its solubility [22, 26, 27]. This polymer is renewable, biocompatible, and biodegradable [24]. Its presence in polymer materials increases their biodegradability [25]. According to Syafiq et al. [28], the mechanical properties of the starch-based films are comparable to currently used plastics. Besides this, the starch films have an advantage - they are edible. Moreover, starch is a low-price polymer [24].

According to the non-toxicity of starch and its unique polymer properties, it is applied in many industries [24]. However this polymer is mainly used in textile [29], pharmaceutical [24], paper [30], printing [31], and cosmetic [32] industries. This polymer would be an excellent material for 
the production of biodegradable disposables if it exhibited hydrophobic properties [25]. The wide range of starch modification methods enables its application in the food industry [33].

\section{Zein}

Zein which belongs to proteins is one of the most frequently used biopolymers from renewable sources [34]. It is obtained only from maize: corn gluten meal (CGM), distillers dried grains (DDG), and dried milled corn [35, 36]. It is the main protein that occurs in corn endosperm cells and its percentage content varies from 35 to $65 \%[35,37]$.

It is a biodegradable and biocompatible material that exhibits hydrophobic, antioxidant, and mucoadhesive properties [38-41]. The solubility of zein depends on the solvent: it is insoluble in water, while anionic detergents, alcohols, and urea (only in high concentration) dissolve it [35]. Solvent parameters (such as $\mathrm{pH}$ and temperature) affect zein structure [42]. According to Arvanitoyannis et al. [43] zein is a brittle material and this characteristic has a negative effect on its structural properties.

Zein is used in the textile, food, and biomedical industries [35]. According to Gonçalves et al. [44], zein-coatings improve the hydrophobic properties of cotton. Due to the United States Food and Drug Administration (FDA) zein is generally recognized as safe (GRAS) [38]. Hence, it is widely used in industries where this polymer could have close contact with the human body. Zein-based edible coatings which contain various antioxidant modifiers are used as food biopreservatives. Zein is applied as a component of adhesives [35]. It is known that the bioactive agents could be encapsulated with this biopolymer [38, 45]. Zein is applied as a material for gene, drug, and vaccine delivery. Tissue engineering is another industry where zein could be potentially used [41]. It could be also implemented as a film and coating material for materials engineering uses. According to the unique properties of zein, it has the potential to replace currently used polymers with the petrochemical origin [42].

\section{Gelatin}

Gelatin is another protein biopolymer [46, 47]. It is obtained from animal skin, bones, cartilages, connective tissues, and fish scales. All the mentioned sources contain collagen [8, $46,48]$. Nowadays, the main source of gelatin is cattle and a pig skin. However, these kinds of animals are suffering from various infectious diseases. Therefore, the alternative sources of gelatin are in constant search. For example, almost one-third of fish waste is skin, scales, and bones which could be used for protein extraction and further gelatin production [25]. It is one of the sustainable ways of waste management which could improve the current ecological state.

According to the natural origin of this polymer, it is completely biodegradable and biocompatible. Gelatin exhibits bioactive (especially antimicrobic), antioxidant, and crosslinking properties [46]. The organic solvents dissolve this material [49]. Gelatin prevents recrystallization and promotes adhesion. However, its adhesive properties depending on the viscosity of the solution. Gelatin is a promising biopolymer for materials engineering applications because of its ability to form films and foams [50]. The fish gelatin is a strong rival to mammal one due to their similar properties. However, the characteristics of fish gelatin depend on the species of fish and the extraction conditions [51].

This biopolymer is widely used in the pharmaceutical, medical, cosmetic, and food industries due to its biocompatible properties $[8,25]$. Gelatin is a feedstock for capsules production [49]. Medical applications of material cover mainly tissue engineering (especially tissue regeneration) [52]. Gelatin-based face masks are widely used by consumers [53]. It is known that this polymer is applied as a compound of lotions and creams [54]. The tasteless edible films and encapsulating materials made from gelatin are used in the food industry $[49,55]$. Gelatin-based biofilms with improved mechanical properties and water resistance are in current research [55]. Moreover, it is applied as a photographic emulsion and surface modifier [46, 55-58].

\section{Polylactide (PLA)}

PLA is classified as a synthetic degradable polymer [10]. PLA is obtained from lactic acid which is mainly isolated from sugar beets, potatoes, and corn [59-61]. There are two main methods of PLA production: polycondensation of lactic acid and ring-opening polymerization of lactide (extracted from lactic acid) [62, 63]. According to Su et al.'s [64] predictions, the amount of produced PLA will increase in the next 2 years.

PLA is a thermoplastic polymer, its properties (clarity and rigidity) are similar to polystyrene (PS) [65]. However, the melting temperature $\left(\mathrm{T}_{\mathrm{m}}\right)$ of PLA is higher and riches $180{ }^{\circ} \mathrm{C}$ [61]. Another advantage of PLA is a lower greenhouse gas emission compared to PS [66]. It is completely biodegradable, dissolves in organic solvents, and swells in a wide range of solvents. The water absorption tendency of PLA affects negatively its degree of crystallinity [61, 67]. The toxicity of polymer is low [68].

According to the biocompatibility of PLA it is widely used in healthcare (e.g. medical and drug) and cosmetic industries. Material is used in prosthetics, orthopedics, reconstructive surgery, tissue engineering and so forth. The PLA microcapsules and microspheres are used to reach the effect of prolonged drug release. Cosmetic application 
of material includes microbeads, face masks, and tissues [68-72]. Due to its relatively high mechanical strength, it is used in the food-packing industry as a vegetable packaging, shrink films, and food trays material. Moreover this it is used for paper bags lamination [73]. The PLA-based packing materials are an environmentally friendly solution that could replace the packaging with petrochemical and nondegradable origin $[74,75]$. Another industry of PLA application is the textile industry. PLA fibers are similar to PET fibers, however, the first ones have several advantages: they are more hydrophilic, have better self-extinguishing parameters, and prevent the multiplication of bacteria. Hence, it is used in clothing, towels, wipes, and filters. Due to sustainability and environmental friendliness, PLA is applied in geotextiles [76]. Moreover, PLA is used for environmental purposes as a sorbent that disposes harmful contaminants contained in water. Additionally, PLA takes part in bioremediation-a technique that uses microorganisms to remove environmental impurities [77].

\section{Polyhydroxybutyrate (PHB)}

PHB is another biopolymer that belongs to the degradable biopolymers subgroup [10]. It is produced by various bacteria and microalgae under certain stress conditions (e.g. carbon excess; oxygen, nitrogen, or phosphate deficiency) and performs a storage function [12, 78, 79]. Bacteria and microalgae are the most common forms of life in the world. However, the cultivation and harvesting of these microorganisms is limited due to the expensive equipment used in these processes [12]. According to Sirohi et al. [80], PHB could be isolated from by-products created during production processes in agricultural, dairy, and food industries.

Certain properties (e.g. physicochemical) of PHB are comparable to fossil fuel-based polymer materials. Despite this, the high biodegradability and biocompatibility of this polymer are known. This fact makes PHB a potential alternative to currently used petroleum-based polymers. However, the high production costs of biopolymer are the main obstacle for its implementation into the industry for commercial purposes. It creates no environmental pollution due to the no-toxicity of its degradation products [78-82]. PLA is characterized as a high crystallinity (degree of its crystallinity rages from 50 to $70 \%$ ) polymer with low water vapour permeability [79, 83-85].

PHB is used in aquacultural, medical, and tissue engineering industries. Moreover, biopolymer is used for equipment production [79, 85]. PHB is applied as a material for the wound dressings and microspheres used in drug delivery systems. Tissue engineering applications of biopolymer and its composites cover sutures, screws, bone plates, staples, rivets, tacks, etc. In the aquacultural industry, it is used as an anti-adhesive agent against shellfish pathogens. While in the agricultural industry it could be applied as an antifouling compound [85]. Also, it is used as an additive for paints and coatings that cause no environmental pollution [86]. It hardly interacts with food, hence it has potential application in the food packing industry [87].

\section{Classification of Polyphenols}

Polyphenols are organic compounds and plant secondary metabolites i.e. final products of enzymatic reactions which occur as a result of metabolism in plants $[8,88]$. Polyphenols are present in fruits, seeds, roots, bark, stalk, timber, and leaves of numerous plants. They are divided into phenolic acids, lignans, stilbenes, and flavonoids [89]. This classification is based on the number of phenolic groups contained in the phenolic ring and also on the method of aromatic rings combining. Each group additionally includes over a dozen subgroups. More than 8000 polyphenol compounds have been discovered $[90,91]$. The majority of polyphenols are compounds of products that play an essential part in the basic human diet. The well-known properties of polyphenols make them interesting modifying additives of biocomposites [92-94]. The next parts of the article perform a detailed analysis of mentioned groups of polyphenols.

\section{Flavonoids}

The best-known group of polyphenols is flavonoids (Fig. 1)—compounds that dye flowers, fruits, and drupes of plants. Flavonoids are the biggest group of polyphenols that includes over 8000 compounds [95, 96]. The number of discovered compounds is constantly increasing [97]. These compounds perform plenty of functions: protecting plants from ultraviolet radiation (UV) damage, creating a biological protective barrier, and exhibit biocidal functions against microorganisms. Furthermore, flavonoids are known as natural antioxidant compounds [98]. Representatives of flavonoids such as flavanones, flavones, flavonols, and isoflavonoids are also well-known for their biocidal properties.

Flavonoids are the promising modifiers of polymer materials due to mentioned properties. These modifiers can be used in the building industry as compounds of products that are exposed to UV radiation (windows, gutters, and other

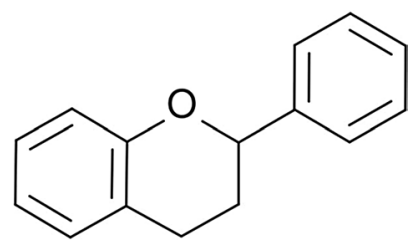

Fig. 1 Chemical structure of flavonoids [99] 
elements manufactured from polymer materials). Increased resistance to UV radiation may improve the aesthetic values which getting worse over time. Window or door elements such as handles doped with biocidal modifiers compounds like flavonoids are necessary in public spaces, especially in current epidemiological conditions. This solution may decrease the number of microorganisms embedded in elements of public usage. In the future, it may reduce the number of infections with various diseases. This group of compounds and their applications are discussed in section 'Classification of Flavonoids'.

\section{Phenolic Acids}

Phenolic acids are the subgroup of polyphenols that contains carboxyl and hydroxyl groups. Phenolic acids can be divided into two groups: the first group contains hydroxybenzoic structures (Fig. 2a) and the second group-hydroxycinnamic (Fig. 2b). Phenolic acids naturally occur in fruits, vegetables, and grains. They are found as compounds in free form (not connected with other compounds) and as connected form. The last form is connected by ether, ester, and acetal bonds with molecules that perform building functions in plants [100]. Proteins, cellulose, and lignin are responsible for these kinds of functions in plants. Phenolic acids also occur in the form that is connected with polysaccharides (starch). They take part in the synthesis of proteins, nutritional and allelopathic processes. During the allelopathic processes, the toxic substances produced by plants are releasing into the environment. The research confirms that substances performing allelopathic functions are also natural bio-stabilizers-substances that inhibit cell division processes (multiplication) of pathogenic microorganisms [2]. These compounds are contained in cucumber and onion [101-105]. Phenolic acids (a)

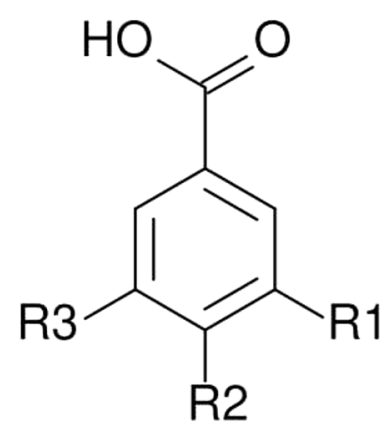

(b)

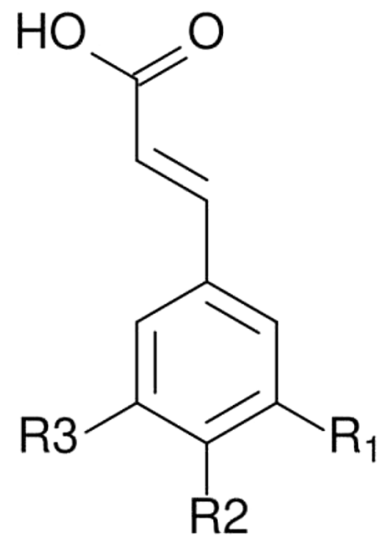

Fig. 2 Chemical structures: hydroxybenzoic (a) and hydroxycinnamic (b) [115] as modifiers of polymer materials may be potentially applied in conditions with a high risk of microorganisms invasion. Products that are used in humid conditions should perform both exploitative and biocidal functions since humidity promotes the multiplication of microorganisms. Phenolic acids fulfill these conditions and can be used as modifying additives of materials used in water transport systems.

The caffeic, gallic, vanillic acids are the representatives of this group [106]. Caffeic acid connected with chitosan exhibits anti-tumor properties what makes it a potential anti-cancer agent [107]. Zein-based and PLA-based coatings which contain caffeic acid can be used in the food packing industry. $\mathrm{PHB} /$ gallic acid nanofibers with antibacterial properties are a novel material for the food packing industry. Chitosan-based mats doped with gallic acid and vanillic acid grafted chitosan (as a wall material) are used for food encapsulation. These materials exhibit antioxidant properties [108-112]. In materials engineering, phenolic acids are used as UV stabilizers in biopolymers (PLA + vanillic acid) [113]. Completely degradable nanoparticles made from PLA which contains caffeic acid could be potentially applied in various industries [114].

\section{Lignans}

Lignans (Fig. 3) are the phenylpropane dimers that are classified as phytoestrogens - the plant origin hormones. Linseed is one of the richest sources of lignans. These phytoestrogens control the growth and development of linseed and also take part in its protection against the harmful effect of UV radiation. They exhibit antifungal and antiparasitic activity. Moreover, lignans are known for their strong antioxidant properties. The solubility of these compounds in the essential oils and resins is high $[98,116]$. This property can be used in the field of materials engineering during resin-based materials processing. The biocidal and antioxidant properties of these materials would be increased. The

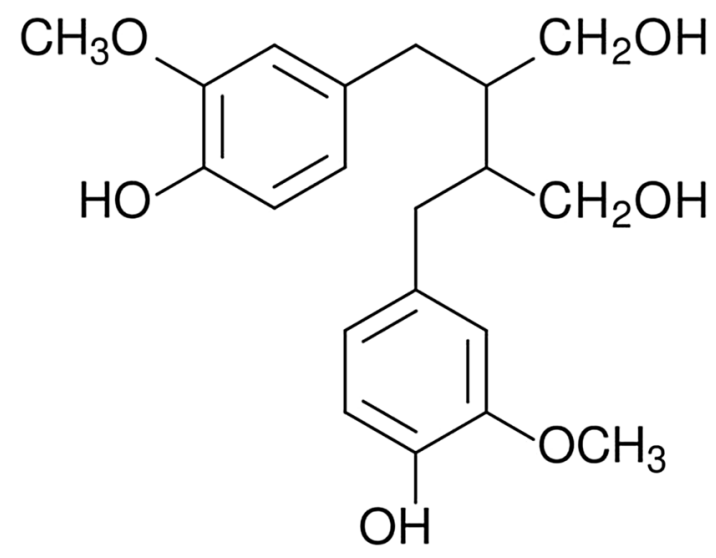

Fig. 3 Chemical structure of lignans [120] 
additives that improve more than one property of the biodegradable materials (e.g. mechanical strength and microbiological resistance) are currently searched.

Certain lignans (phyllanthin and silymarin) are implemented into biopolymers. Chitosan-based microcapsules with phyllanthin have a potential application in the pharmaceutical industry [117]. Cellulose biocomposites containing zein/silymarin nanoparticles could be used in food packing. The strong antioxidant properties of this packaging elongate the shelf life of products packed in it [118]. Silymarin improves the resistance of biopolymer blends (PLA/ PHB) on thermo-oxidative degradation. Therefore it could be applied as a thermooxidative stabilizer in materials engineering [119].

\section{Stilbenes}

Stilbenes (Fig. 4) are the organic compounds contained i.a. in berries, grapes, and nuts. These substances have a complicated structure. They exhibit antioxidant and antimicrobic properties and have the ability to polymerization. The antioxidant mechanism of stilbenes is based on the stimulation of proteins and enzymes contained in plant cells. Stilbenes are not widely spread and occur only in 30 plant species. In the years 1995-2008 approximately 400 new stilbenes were discovered [98, 121]. This group of substances exhibits both biocidal and antioxidant properties. The presence of these modifying additives could increase the service life of final products which could be exposed to pathogenic microorganisms and adverse climatic conditions (e.g. UV oxidation).

The resveratrol and piceatannol belong to stilbenes. Biopolymer-based nanoparticles loaded with resveratrol have a potential application in the drug industry. The delivery of resveratrol in nanoparticles improves its solubility in the human body $[122,123]$. Biopolymers/resveratrol materials are used as repairing scaffolds in tissue engineering [124]. The gelatin/zein mats and pectin/gelatine films

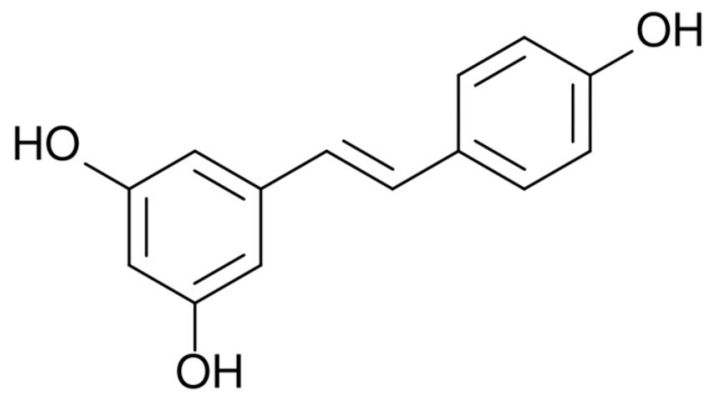

Fig. 4 Chemical structure of stilbenes [120] containing resveratrol are used as an active packaging material that elongates the shelf life of food $[125,126]$.

It is known that resveratrol improves the photo-oxidative and thermal stability of PLA and could be applied in materials engineering [127]. Piceatannol is a stilbene with strong anti-cancer, anti-viral, anti-inflammatory, and antioxidant activity which is used in the pharmaceutical industry. The chitosan-PLA nanoparticles and zein nanospheres have a potential application as drug carriers for the piceatannol $[128,129]$.

\section{Classification of Flavonoids}

\section{Flavanones}

Flavanones is a small subgroup of flavonoids that takes a big part in medicine. Citrus fruits are the richest source of flavanones. Citrus peel has the greatest concentration of these active substances. Due to their bioactive properties (effecting on human health), citrus fruits extracts are used as well as immunostimulants, preservatives and cleaning agents [130]. Pinostrobin, naringenin, and hesperidin are the most known flavonoids (Fig. 5).

Pinostrobin is obtained from plants Renealmia alpinia and Alpinia zerumbet $[131,132]$. It is the dominant polyphenol contained in certain propolis species [133]. Due to the research described in [134], this substance has a biostatic effect against Helicobacter pylori and Herpes simplex virus type I.

Chitosan/sodium alginate nanoparticles doped with pinostrobin could be used in the pharmaceutical industry as an anticancer drug [135]. Biopolymer films doped with propolis extract have a potential application as an active packaging material [133].

Naringenin contained in pomegranate juice is a naringin derivative. This compound caused the characteristic bitter taste of pomegranate [136, 137]. Naringenin is also contained in peach drupels, citrus fruits, and tomatoes. Apart from many anticancer properties, naringenin exhibits biostatic activity against $H$. pylori strain and inhibits the enzymes secreted by it [138]. Moreover, this compound exhibits antioxidant and anti-inflammatory properties and also can be used as the agent that inhibits the development of the SARS-CoV-2 virus [139].

Chitosan nanoparticles loaded with naringenin are used in the pharmaceutical industry due to the anti-cancer properties of naringenin [140]. Biopolymer nanoparticles doped with naringenin increase the water solubility of flavanone. This solution has potential application in drug delivery systems [141]. The effectiveness of chitosan-based nanoemulsions doped with naringenin in skin injuries treatment has been proved [142]. 
Fig. 5 Chemical structure of: pinostrobin (a) [131], naringenin (b) [149], and hesperidin (c) $[150]$ (a)<smiles>COc1cc(O)c2c(c1)O[C@H](c1ccccc1)CC2=O</smiles>

(b)<smiles>O=C1CC(c2ccc(O)cc2)Oc2cc(O)cc(O)c21</smiles><smiles>COc1ccc(C2CC(=O)c3c(O)cc(O[C@@H]4O[C@H](CO[C@H]5O[C@@H](C)[C@H](O)[C@H](O)[C@H]5O)[C@@H](O)[C@H](O)[C@H]4O)cc3O2)cc1O</smiles>

Hesperidin like naringenin is contained in citrus fruits and is active against some types of viruses such as Herpes, Poliomyelitis, and Paramyxovirus. Due to the latest research that shows low cytotoxicity of hesperidin, it can be used as an active compound of antivirals against coronaviruses [143-145].

The biopolymer-based hydrogels containing hesperidin in the concentration of $10 \%$ could be used as a wound healer agent [146]. Gelatin films with chitosan nanoparticles doped with hesperidin have been considered as an active packaging material [147]. Biopolymer-based materials with hesperidin have a potential application in the food packing industry due to their antioxidant properties and environmental friendliness [148].

\section{Flavones}

As well as previous group flavones are contained in citrus fruits and their juices [151]. The biological activity was observed in luteolin and apigenin which are classified as flavones (Fig. 6). Luteolin is contained in red onion, kohlrabi, lettuce, arugula, carrots, red and yellow peppers, beetroot, green beans, and spinach. The mechanism of biocidal activity is based on the inhibition process of DNA (nucleic acids are built of nucleotides connected with phosphodiester bond) polymerase [8]. Luteolin exhibits biological activity against the flu virus, Herpes virus, and some Propionibacterium and Staphylococcus bacteria [152, 153]. It is biostatic against Chlamydia pneumoniaem,
Fig. 6 Chemical structure of: luteolin (a) [159], apigenin (b) [149] (a)<smiles>O=c1cc(-c2ccc(O)c(O)c2)oc2cc(O)cc(O)c12</smiles>

(b)<smiles>O=c1cc(-c2ccc(O)cc2)oc2cc(O)cc(O)c12</smiles> 
Trichophyton rubrum, and T. mentagraphytes bacterias. The effectiveness of luteolin against some fungi is comparable to the effectiveness of ketoconazole which is classified as an antifungal drug [152].

Luteolin is used in the pharmaceutical industry, however, the low absorption (bioavailability) in the human body is one of its disadvantages. The biopolymer drug carriers (zein, chitosan, etc.) make it more bioavailable [154-156]. The elongated antioxidant activity of luteolin encapsulated with starch nanoparticles is proved. This kind of nanoparticles could be used in both the drug and food industries [157]. The antioxidant and biocidal properties of luteolin make it an interesting additive for chitosan-based active packing films [158].

Apigenin is contained in i.a. the chicory, pak choi cabbage, and red onion [160]. Clinical trials prove the biostatic activity of apigenin against SARS-CoV-2 and its anti-HIV effect that was similar to the effect of the nelfinavir-the HIV drug [139]. Due to this observation, the substances used in the treatment of HIV can also be applied in cases of coronavirus infection. Apigenin is a natural antioxidant and this property can increase the service life of polymer materials. The cosmetics with an antioxidant effect are in high demand, therefore the apigenin can be potentially implemented in this industry [149]. Luteolin and apigenin constitute a new interesting application-as active ingredients of polymer materials with biocidal properties.

As well as luteolin, apigenin is a flavone with low bioavailability. This property could be improved with its introduction into zein/lecithin nanocomposite. This material has a potential application in the pharmaceutical, cosmetic, and food industries [161]. Chitosan also enhances the solubility of apigenin and could be used as its carrier in drug delivery systems [162]. The apigenin hydrogels based on biopolymers [gelatin, chitosan, and polyethylene glycol (PEG)] promote diabetic wound treatment. Hence, its prospects in diabetic skin injuries therapy is huge [163]. Chitosan-based nanogels loaded with apigenin stop the cancer cells proliferation, therefore the potential application of these materials in oncology is justified [164]. Starch-apigenin complex has a potential application as a supplement supporting stable glucose level in blood. In materials engineering, apigenin could be used as a thermal stabilizer of starch [165].

\section{Flavonols}

Kaempferol, quercetin, and myricetin are the best known and the most common flavonols (Fig. 7) [160, 166]. This group performs different functions such as photoprotection, i.e. protects plants against the harmful effects of UV and parasites, gives plants colour, and also prevents oxidation processes [167]. The biological activity of flavonols depends on their chemical structure and the presence of hydroxyl groups [166].

Kaempferol occurs in many plant species, however the highest content of this substance is found in several plant species: acacia, saffron, aloe, ginkgo, goatweed, leaf flower, and rosemary [170, 171]. Among berries, kaempferol occurs in blackcurrants, gooseberries, and strawberries $[160,172]$. This substance also exhibits antioxidant and antimicrobial properties [170]. Kaempferol is a nontoxic substance and has the ability to inhibit inflammatory processes caused by $H$. pylori which take place in the human body [172, 173].

Zein nanoparticles coated with alginate and chitosan are used for kaempferol encapsulation in order to increase its absorption in the blood. This form of kaempferol administration is a prospective solution for drug delivery systems [174]. Zein-kaempferol coatings improve the mechanical and bioactive properties of scaffolds, thus their tissue engineering application is justified [175]. The biopolymerbased membrane doped with kaempferol could be potentially applied as an infected wound dressing [176]. The study of gelatin nanoparticles doped with kaempferol confirms that it could be used as an eye drops for certain eye diseases [177]. The lecithin/chitosan nanoparticles loaded with kaempferol has a potential application as an antifungal agent [178]. (a)<smiles>O=c1c(O)c(-c2ccc(O)cc2)oc2cc(O)cc(O)c12</smiles>

(b)<smiles>O=c1c(O)c(-c2ccc(O)c(O)c2)oc2cc(O)cc(O)c12</smiles><smiles>O=c1c(O)c(-c2cc(O)c(O)c(O)c2)oc2cc(O)cc(O)c12</smiles>

Fig. 7 Chemical structure of: kaempferol (a), quercetin (b) [168], and myricetin (c) [169] 
Quercetin is a substance with antioxidant properties. It stimulates the human enzyme system which is responsible for metabolic processes [96]. This substance has been applied in silver nanoparticles processing and replaced widely used reducing agents which pollute the environment. Silver nanoparticles with biocidal properties that are obtained with quercetin are called "green" due to the ecological method of their production [179, 180]. Quercetin exhibits biostatic properties and the activity of these properties depends on the type of bacteria. It is a strong agent that inhibits Gram-positive bacteria, however, its activity against Gram-negative bacteria is weak. Research proved that quercetin inhibits the growth of several bacterial strains: Escherichia coli, Staphylococcus aureus, Pseudomonas aeruginosa, and Salmonella enterica [181]. The literature overview reveals that both quercetin and kaempferol are bioactive against SARS-CoV-2 and inhibit metabolic processes of this virus type [139]. This property is crucial in the current pandemic situation. Previously mentioned modifiers have a potential application as biocomposites additives. These modifiers could limit the spread of the pathogenic virus on the surface of materials. Due to their properties, the biocomposites that contain this type of modifying additives could be applied in the public spaces and medical industry.

Zein is used for quercetin encapsulation and as a drug carrier. Due to the bioactive and antioxidant properties of the material, it could be applied in the pharmaceutical, healthcare, food, and food packing industries [182-185]. The potential biomedical applications are based on the implementation of quercetin encapsulated with biopolymers [186, 187]. It has been proved that biopolymer-based hydrogels containing quercetin regenerate bones. Therefore, these hydrogels could be applied as scaffolds in tissue engineering [188]. Chitosan, chitosan/gelatin, and starch/ gelatin films loaded with quercetin elongate the shelf life of food due to the above-mentioned properties. Hence, it is well-suited for food packaging applications. Additionally, these films are edible, which makes them even safer for humans [189-193]. The presence of quercetin in PLAbased films makes them interesting materials for active packaging due to the antibacterial activity [194]. Lecithin/chitosan nanoparticles doped with quercetin have a potential application in functional food (food that besides its nutritional value prevents diseases or supports health) production [195]. The thermal stability of starch doped with quercetin was greater than the pure starch one. This fact suggests that quercetin could be potentially used during polymer processing [196].

Another flavonol is myricetin that occurs in parsley, marigold, berries, grapes, oranges, broad beans, herbs, wine, and tea [197-200]. The characteristic feature of this compound is the high melting point $-357^{\circ} \mathrm{C}$. The activity of myricetin against $S$. aureus has been reported in [153]. It is a natural antioxidant compound that neutralizes free radicals. The application of this substance in various industries is complicated due to its physicochemical properties, which are poorly understood so far [198].

Chitosan, chitosan-based, and starch materials could be applied as myricetin carriers used in the therapy of various diseases [201-203]. Certain biopolymers improve the bioavailability of myricetin [204]. Chitosan loaded with flavonols (myricetin, kaempferol, and quercetin) is considered to be an excellent active packaging material due to its modified properties (antimicrobial, antioxidant, etc.) of chitosan [205].

\section{Isoflavonoids}

Isoflavonoids occur in various plants: red clover, lentil, spinach, some species of burclover, meadow-grass, coffee beans, plants as the broad bean, and white kwao krua which belong to the bean family [206]. However, soybeans have the highest concentration of isoflavonoids. In the medical industry, the most commonly used isoflavonoids are genistein, daidzein (Fig. 8), and glycitein (Fig. 9) due to their biological activity [207].

Genistein naturally occurs in beans, potatoes, coffee beans, babchi plant, and red clover [208]. This substance inhibits the development of several types of bacteria: $S$. aureus, H. pylori, Bacillus anthracis, and Vibrio vulnificus. Further research does not confirm a similar effect of genistein on E. coli, Lactobacillus reuteri, Shigella sonnei, and Klebsiella pneumoniae. It suggests that the biocidal properties of genistein depend on the properties of selected bacteria
Fig. 8 Chemical structure of: genistein (a) [230], daidzein (b) [220] (a)

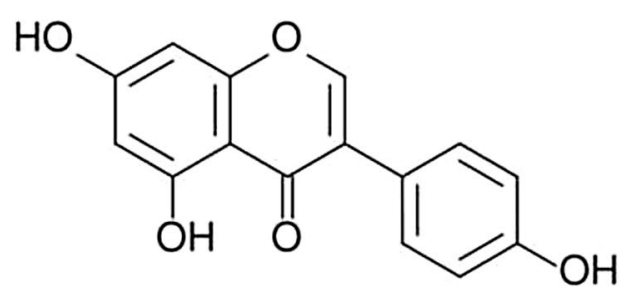

(b)<smiles>O=c1c(-c2ccc(O)cc2)coc2cc(O)ccc12</smiles> 
<smiles>COc1cc2c(=O)c(-c3ccc(O)cc3)coc2cc1O</smiles>

Fig. 9 Chemical structure of glycitein [235]

[209]. Genistein is a natural antioxidant and also antiallergic and anti-inflammatory agent [210, 211].

Genistein encapsulated with biopolymer nanoparticles is a promising material for food and pharmaceutical applications [212-214]. Gelatin and starch could be used as genistein carriers. A high possibility of commercialization of these drug carriers is caused by the low manufacture costs $[215,216]$. PLA improves the solubility of genistein. Due to the non-toxicity of PLA and therapeutic properties of isoflavonoid, the pharmaceutical application of their blend is justified [217]. It has been proved that the bioactive properties of genistein contained in gelatin do not change within 3 months. This suggests, that gelatin is an excellent matrix for genistein storage [215]. Chitosanbased nanofibers loaded with genistein could be used for biomedical purposes [218]. Chitosan doped with antioxidant genistein can be potentially used as a functional food additive [219].

Daidzein is another substance that belongs to isoflavonoids. This isoflavonoid occurs in various subspecies of the bean family, red clover, and kudzu roots [220, 221]. The substance exhibits antibacterial and fungicidal properties [222]. The conducted research proved, that daidzein is an auxiliary substance of several antibiotics. S. aureus is resistant to methicillin, but its combination with daidzein makes it active against this type of bacteria [223]. The activity of daidzein against $P$. aeruginosa has been proved. Moreover, it exhibits antioxidant, anti-inflammatory, and anti-aging properties [220, 224].

Daidzein is a natural adhesive agent which could be applied in certain non-metallic coatings which are widely used in the automotive, furniture, and cosmetic industries [222]. The possibility to improve the adhesion of this type of coatings is crucial due to their low durability and exposure to abrasion during their exploitation. The main reason of the paint coatings chipping is the disruption of their integrity caused by low adhesion between the coating and coated material. The search for an agent which increases adhesion is in the constant process due to the needs of coated products users. The non-toxicity and the renewability are extremely desired in modern materials engineering. Therefore these features of daidzein make it even more attractive as a modern adhesive agent.
Chitosan, starch, gelatin, poly(lactic-co-glycolic) acid (PLGA), and PHB could be used as daidzein carriers which improve its bioavailability [225-229]. This fact shows the pharmacological value of these material blends and daidzein in particular.

Glycitein occurs in soybean and it is responsible for the characteristic taste of products made of soybean [206, 231]. The substance exhibits antibacterial and fungicidal properties against Colletotrichum gloeosporioides [232, 233]. It is an antioxidant compound [234]. According to the abovementioned properties of this isoflavonoid, it has potential applications in various industries (cosmetic, medical, pharmaceutical, and polymer). However, the current literature analysis suggests that glycitein is not well-exanimated yet. Therefore its potential applications as a biopolymer-modifier are poorly studied.

\section{Blackcurrant Extract}

One of the richest sources of polyphenols is a blackcurrant bush. Although the extract obtained from each part of the plant exhibits biocidal properties. The comparison of the amount of the polyphenols in various fruits shows their greater content in the blackcurrant. The content of polyphenols in this plant is $340 \mathrm{mg}$ in $100 \mathrm{~g}$ of blackcurrant seeds.

The high content of polyphenols in blackcurrant extract made it a promising modifier of polymer materials due to its non-toxicity and easy cultivation in the middle European climate. Blackcurrant extract is obtained from various parts of the plant such as fruits, leaves, seeds, and buds. However, it has been proved that the blackcurrant buds are the richest source of biocidal substances contained in blackcurrant [236].

There is a wide spectrum of biocidal properties of this extract. It exhibits biocidal activity against Candida albicans which belongs to fungi. The mechanism of fungicidal activity is based on fungi cell wall deformation which leads to the leak of the internal substance. This process initiates the inevitable death of the microorganisms [237]. Blackcurrant buds exhibit antimicrobic properties owed to kaempferol, quercetin, rutin, and myricetin contained in them [238]. According to the literature review extract from the blackurrant buds exhibits biological activity against several bacterial strains: B. subtilis, Listeria monocytogenes, $S$. aureus, E. coli, $P$. aeruginosa, and Acinetobacter bacteria. The biostatic activity of blackcurrant extract on C. albicans, Alternaria alternata, and Aspergillus niger depends on blackcurrant variety [236, 239]. The effect of the extract on certain fungi strains has been compared to the effect of fluconazole (antibiotic). According to the conducted research, the plant extract is 
more effective against microorganisms than certain antibiotics [239]. The extract exhibits anti-inflammatory and antioxidant properties due to the content of ascorbic acid which is a natural antioxidant $[236,240]$. The blackcurrant berries contain calcium, aluminium, magnesium, and iron which give them their characteristic navy blue colour. The red shade of blackcurrant pulp is caused by the presence of potassium [240]. The pigment substances contained in the blackcurrant berries extract limit its application as modifying additive of biodegradable polymer materials. However, this property can also be an advantage of this modifier in cases where the colour of products is desired. Besides biocidal and antioxidant properties, the extract performs pigment functions which could reduce the number of additives contained in polymer biocomposites. It is another advantage of this extract.

The influence of the blackcurrant extract encapsulated with gelatin on the blood flow has been confirmed. Therefore it can be used for pharmaceutical purposes [241]. The effect of blackcurrant extract on the biopolymer mixtures was investigated. It was founded, that certain blackcurrant concentrations improve the crosslinking, hydrophilic, and optical properties of materials. Hence, this fact makes these materials an interesting solution that could be implemented in the optoelectronic industry [242]. The colouring properties of the blackcurrant anthocyanins are known. The biopolymer-blackcurrant anthocyanins mix is an excellent substitute for the currently used dyes with the synthetic origin [243]. Due to the unique properties (bioactive and antioxidant) of blackcurrant, its complexes with proteins could be applied as an additive in functional food [244]. The starch-blackcurrant complexes have the same application. It has been founded that blackcurrant modifies the physicochemical properties and colour features of the biopolymer [245]. The presence of blackcurrant in gelatin increases its hardness and brittleness which are desired in the food industry [246].

\section{Tannic Acid}

Tannic acid (Fig. 10) is a substance that occurs commonly in the natural environment as a plant compound [247] This substance is classified as phenol-the organic compound which includes one or more hydroxyl groups connected with the aromatic ring [8]. It is noticed that this substance occurs in almost all aerial parts of plants [247]. The richest source of tannic acid is galls-growths with hardened structures. The galls are appearing as a result of certain insect spices preying and also as by-products produced by mites, fungi, and bacteria. Oak galls, also known as oak apples, are created by two insects that belong to the Cynipidae family. One of these insects called the gall-fly is probably the main reason of the galls creation [248]. Besides oaks, galls occur in roses, apples, willows, poplars, beeches, acacias, redwoods, and pistachio trees [249-251]. Tannic acid also occurs in other plants-in the walnut tree bark which is common in middle Europe, in pine and mahogany which grows in Central America. It is the ingredient of strawberries and nettle [251].

Tannic acid exhibits antioxidant properties and is active against viruses, bacteria, and fungi [254-260]. Flu virus and HIV are susceptible to tannic acid. This substance exhibits a bacteriostatic effect against several Gram-negative bacterial strains (Cytophaga columnaris, H. pylori, E. coli, and $K$. pneumoniae) and Gram-positive bacterial strains ( $S$. aureus and L. monocytogenes, B. subtilis) [254-256]. The antimicrobial activity depends on the type of bacteria-the inhibiting effect was stronger against Gram-positive bacterial strains. The tannic acid is also antimicrobic against $C$. albicans which belongs to fungi [254]. Kim [255] proved that the thermal treatment of tannic acid increases its antimicrobic properties.

The combination of several properties (biocidal, antioxidant, and crosslinking) in one additive makes tannic acid a potential modifier that could be applied in polymer biocomposites. When the tannic acid contacts with a solvent, it releases dyes which makes it a natural colouring agent. According to this, tannic acid could replace synthetic dyes which are currently used. The main disadvantage of polymer biocomposites is a low adhesion between phases which could be improved with tannic acid introduction. It increases the mechanical strength of the biocomposite and expands the area of the final product application. The application of tannic acid in biocomposites could probably increase the service life of material due to the reduced amount of microorganisms present on their surface. Moreover, tannic acid could inhibit internal and external antioxidant processes.

This type of biocomposites has a potential application in the medical, catering, and other industries where microbiological hygiene is required. Tannic acid is a promising

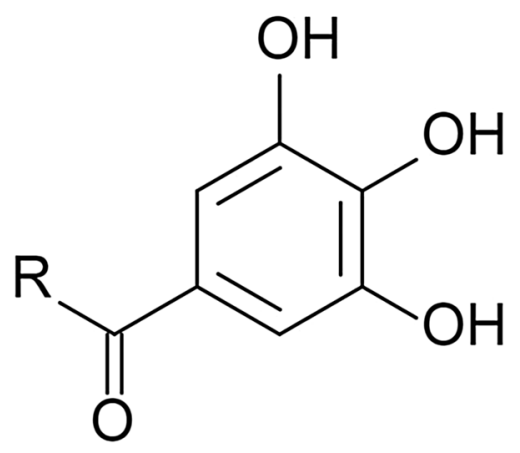

Fig. 10 Chemical structure of tannic acid [252, 253] 
modifier with biocidal properties which could be applied in the packaging industry due to its non-toxicity. The antimicrobic and antioxidant properties of tannic acid are confirmed with research conducted on the biodegradable packaging made of starch doped with this substance [256]. This type of packaging can certainly be implemented in the industry and have the potential to replace the currently used packaging made of crude oil. Polymer biocomposites made of chitosan containing tannic acid are interesting materials with potential application in cosmetology as acne patches [257]. The colonization of the sebaceous glands by the bacteria Propionibacterium acnes is one of the reasons of acne [261]. The biocomposites with tannic acid probably could lead to the death of these pathogenic microorganisms. However, this type of research is not done so far and the effect of tannic acid on these bacterial strains is not investigated yet.

These complexes could be applied in drug or supplement delivery systems as a carrier due to the non-toxicity and ability to controlled supplement/drug release [262]. Gelatin microspheres containing tannic acid could be applied for nutraceutical purposes [263]. Gelatin/tannic acid films exhibit antibacterial properties which are desired in biomedical materials [264]. Gelatin/tannic acid hydrogels with shape memory are interesting materials for potential biomedical and robotic applications [265]. Biocomposite nanofibers with tannic acid could be used as a biocompatible wound dressing material with an antibacterial effect [266]. The zein/tannic acid complexes acid have a wide range of applications in food and cosmetic industries due to their stabilizing and crosslinking properties $[267,268]$. Zein/tannic acid coatings elongate the shelf life of fruits, therefore this kind of edible layers could be used as nontoxic biopreservatives in the food industry [269]. Zein particles modified with tannic acid improve mechanical properties and hydrophobicity of gelatin-based composites for food packing [270]. The gelatin doped with silver nanoparticles and tannic acid is another material for potential food packing application [271]. The chitosan films containing tannic acid could have the same application [272]. Tannic acid improves interfacial adhesion in composites and as a result-mechanical properties of ones. Therefore, it could be used in polymer biocomposites production [273, 274]. Chitosan/tannic acid coatings applied on biocomposites fillers increase the fire resistance of biocomposites. This kind of coatings has a potential application in materials engineering [275].

\section{Betulinic Acid}

Betulinic acid belongs to triterpenoids which are the triterpenes derivates. The source of the betulinic acid is i.a. varied birch species [276, 277]. This substance is obtained from betulin (BE) shown in Fig. 11. The betulin occurs in plants such a birch, London plane tree, jujube, Caucasian alder, thistle, and rosemary [278, 279]. Among mentioned plants, the highest concentration of betulin is found in birch bark which consists of inner and outer parts. It has been proved, that the content of betulin in the outer bark ranges from 30 to $35 \%$ and this value depends on the birch variety [276, 280]. The white colour of the tree is caused by the presence of betulin, which is a natural dye. This substance was discovered in 1788 by a pharmacist and chemist Tobias Lowitz [281].

Betulinic acid exhibits antiviral properties against HIV due to the functional groups that occur in it at carbon atoms C-23 and C-28. Betulinic acid is biocidal against the Herpes simplex virus (type 1 and type 4) and several Enterovirus viruses [284-286]. Some of the betulin derivatives are also exhibiting antiviral activity. Bevirimat which is produced by the chemical modification of betulinic acid exhibits the highest activity against HIV and inhibits HIV-1 and HIV-2 [287]. This substance also inhibits the advanced stage of HIV-1. Due to the mentioned properties of bevirimat, it is a promising compound that could be used as an anti-HIV drug [279, 288].

Antibacterial property is another advantage of betulinic acid. According to conducted research, the tannic acid is the only betulin derivate with biostatic activity against $E$. coli,
Fig. 11 Chemical structure of: betulinic acid (a) and betulin (b) [282, 283] (a)

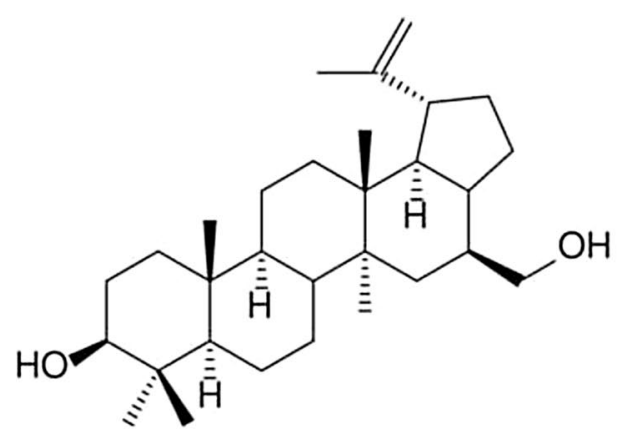

(b)<smiles>C=C(C)[C@@H]1CCC2[C@@H](C(=O)O)C[C@]3(C)C4CC[C@@H]5C(C)(C)[C@H](O)CC[C@]5(C)[C@H]4CC[C@]3(C)[C@H]21</smiles> 
P. aeruginosa, and Enterobacter aerogenes. It is probably caused by the structure of mentioned bacteria which belong to Gram-negative bacteria. They have an extracellular membrane which could be an obstacle during the penetration of active compounds-betulin derivatives. Furthermore, betulinic acid exhibits biostatic activity against $E$. faecalis bacterial strain and inhibits the growth of these bacterial colonies by $56 \%$ [289]. The antibacterial activity of betulinic acid against bacteria $P$. aeruginosa, E. coli, and $S$. aureus bacterial strains is caused by increased production of superoxide anion radicals which cause oxidative stress in bacterial cells. This process is unfavorable for bacterial cells and most often leads to their death. The oxidation process of bacterial cells has been proved by increased concentration of malondialdehyde which is an indicator of oxidative stress and cell destruction [290]. According to the current literature state, the substance also inhibits the SARS-CoV virus [291]. The inhibiting mechanisms of viruses can be divided into two groups which are implemented at different stages of viral development. The processes which belong to the first group are activated during the cell penetration by the virus. These processes make it difficult for the virus to cross the cell membrane. The second group is based on inhibiting the process of viral replication caused by the effect of betulinic acid on SARS-CoV 3CL protease [291]. Ascorbic acid is a substance that has a synergistic effect on betulinic acid.

The literature overview allowed us to estimate the validity of betulinic acid application as a modifier of biodegradable polymer materials. The estimation was based on the previously described properties of the substances. Betulinic acid is a new substance in the polymer industry, therefore the information about its behavior and effects on the polymer matrix is very limited. However, there is a reliable report-a patent invented by scientists from the University of Silesia in Katowice, Poland, and the Medical University of Silesia in Katowice. The method of obtaining betulin-modified thermoplastic polymers is the subject of this patent. The characteristic features of this polymer are antibacterial and anti-inflammatory properties [292]. This is a breakthrough discovery because betulin and betulinic acid have similar properties. This fact suggests that polymer materials containing betulinic acid would probably exhibit antibacterial properties as well. This will undoubtedly extend the service life of final products and increase the area of their potential application. Such areas may be industries where sterile conditions are desired.

The effectiveness of betulinic acid against parasites has been proved via testing chitosan nanoparticles loaded with betulinic acid [293, 294]. Certain biopolymer coatings containing betulinic acid exhibit anticancer properties [295-297]. The same properties were noticed in biopolymer-based nanoparticles loaded with betulinic acid [298, 299]. Therefore, the pharmaceutical potential of betulinic acid is huge. From the literature overview, it could be concluded, that the applications of betulinic acid as a biopolymer-additive in other industries have not been described yet.

\section{Lapachol}

Lapachol is a compound that occurs both in the inner part of the bark and in the heartwood of Tabebuia trees, commonly found in South and Central America [300]. In the colloquial language of Brazilians, this tree species is also called taheebo, pau d'Arco, or lapacho which probably gives the name to the active substance contained in the tree bark [301, 302]. According to the literature reports, the other plants which belong to the Bignoniaceae family (as well as Tabebuia does) also include lapachol in their timber [303, 304]. The Tabebuia bark has been already used by Incas in ancient times-the infusion of chopped tree bark was applied for medicinal purposes. In 1882 lapachol was extracted by Italian phytochemist-Emanuel Paterno for the first time [301, 302, 306, 305]. Lapachol (2-Hydroxy-3-(3-methyl2-butenyl)-1,4-naphthoquinone) is classified as naphthoquinone [303]. Naphthoquinones are organic compounds derived from naphthalene. The presence of ketone groups $(\mathrm{C}=\mathrm{O})$ in the naphthoquinones structure is known $[8,307]$. The chemical structure of lapachol is illustrated in Fig. 12.

Lapachol exhibits biological activity against microorganisms. Its biocidal mechanism is based on the initiation of oxidation processes and enzyme inhibition. Both reactions occur in cells [300]. It has been proved that the biological activity of naphthoquinones depends on their structure [308]. The biological effect of this substance is similar to the effect of antibiotic amphotericin B. Lapachol is effective against the following bacterial strains: H. pylori, Streptococcus, Enterococcus, Clostridium, Staphylococcus, and Bacillus which are hazardous for human health. The antifungal activity extends to Candida species and Cryptococcus neoformans [300]. Lapachol like the majority of naphthoquinones exhibits colouring properties and could be used as the yellow pigment [301, 303, 304]. It is also a natural antioxidant agent [309].

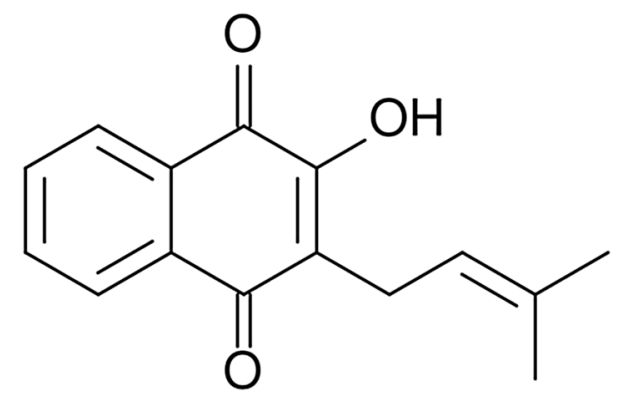

Fig. 12 Chemical structure of lapachol 
The unique properties of lapachol and its toxicity against microorganisms are advantages. The resistance of polymer materials on the microorganisms is crucial due to their common exposure to the microorganisms. Hence, the bark of Tabebuia which contents lapachol is a promising material that could be introduced in biodegradable polymer biocomposites. The modification of biocidal and mechanical properties of biocomposites with the lapachol does not pollute the environment. The biocomposite that consists of the biodegradable PLA matrix and the reinforcement such a Tabebuia bark is completely biodegradable. This type of biocomposite has been examined by authors. The manufacturing of the biocomposite was carried out in several stages-by extrusion with granulation and injection. The enzymatic biodegradation studies were performed according to the method contained in the article [310]. These studies lasted 8 weeks. Due to our studies [311], the increase of bark content in biocomposite leads to the increase of the percent mass loss which proves higher biodegradability of biocomposite. The same dependence has been noticed during the mechanical studies. The increased content of Tabebuia bark in the biocomposites increases the tensile modulus of materials. The presence of lapachol contained in the Tabebuia bark improved the thermal durability of the biocomposites. However, more detailed research of lapachol influence on the thermal properties of PLA is recommended. According to biocidal studies, the antimicrobic activity of biocomposites was lower than the one mentioned in [301]. The decrease of biocidal activity of the biocomposites is caused by the high processing temperatures (e.g. extrusion and injection molding) applied.

The lapachol derivative-lapachol sodium salt exhibits biological activity and could be used as a drug. The chitosan flakes/lapachol sodium salt complex increases the bioavailability of the latter [312]. The lapachol derivative lapazine has a potential application as a drug used in infectious diseases treatment. The studies of alginate/chitosan microparticles loaded with lapazine prove it. $\beta$-Lapachone is another lapachol derivative with a wide range of therapeutic properties. However, the high toxicity of $\beta$-lapachone is an obstacle to its implementation into the pharmaceutical industry. The studies on the $\beta$-lapachone connected with chitosan confirms the decrease of agent toxicity. This fact increases the probability of its application in the pharmaceutical industry [313, 314]. According to Pereira et al. [315], starch could be used as a lapachol carrier in drug delivery systems.

\section{Allicin}

Allicin (diallyl thiosulfonate) (Fig. 13) is the main ingredient of garlic, onion, and clove extracts which exhibits biocidal properties $[8,316]$. It creates during garlic or onion

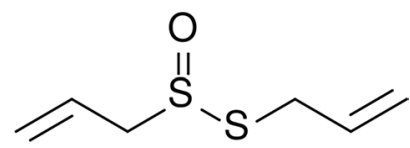

Fig. 13 Chemical structure of allicin [319]

crushing [317]. This compound belongs to phytoncides- the bioactive compounds that are produced by selected plants. Phytoncides are defined as natural antibiotics. The biocidal properties of garlic extract were observed at the end of the nineteenth century by Louis Pasteur. The isolation of allicin from cloves was carried out by Chester John Cavallito and John Hays Bailey in 1944 for the first time [318]. The highest concentration of allicin is found in the garlic extract. For this reason, the plant is applied in traditional medicine. Moreover, due to its high taste attributes it is used in almost every cuisine of the world. The wide spectrum of garlic biocidal properties has caused a growing interest in the modern scientific world including materials engineering.

Allicin is a substance that exhibits a strong antioxidant effect based on free radicals inhibiting [318, 320]. It has antifungal and antimicrobic (the antibacterial activity against several Gram-positive and Gram-negative bacterial strains was noticed) properties [319, 321, 322]. The mechanisms of the biocidal action of the substance are not well known so far, but literature reports show that the formation of allylsulfide compounds changes L-cysteine, which is a free amino acid [318]. Allicin has a cytotoxic effect on proteins contained in microbes cells. The penetration of parasitic cells by allicin leads to their death [323].

According to the conducted research, the highest activity of allicin (more than 86\%) was noticed on the 3rd day of studies while this percentage value changed over time. The last measurement has been done on the 11th day of studies and the percentage value of substance activity decreased by almost $1 / 3$ compared to the 3 rd day of studies. It was probably caused by the high volatility of allicin. However, the substance had high biological activity even after 11 days of exposure to the bacteria [324]. The allicin is also bioactive against several fungi and protozoa [325].

Due to the wide spectrum of biocidal properties of allicin, it can replace currently used additives which give the resistance of the biodegradable material to the adverse effects of pathogenic microorganisms. However, one of the main disadvantages of this compound is the characteristic sulfuric smell which is associated with the garlic smell. According to this, allicin can be applied in biodegradable materials which have limited contact with humans. It can also be used in conditions where the controlled development of microorganisms on the surface of the material is desired.

Cellulose nanoparticles doped with allicin exhibit antimicrobial properties which suggest that this complex could 
be used in food, food packing, and textile industries to limit microbial proliferation [326]. The starch-based wall material is used to produce allicin microcapsules which can be used as a biopreservative in the food industry [327]. The chitosan/allicin complex exhibits grown antimicrobial activity, therefore this material is suitable for the food industry applications [328-330]. Allicin encapsulated in chitosan/starch could be used as a nitrogen fertilizers additive. The presence of allicin elongates the release of the nutrients in the soil which is desired in perennial plants cultivation [331]. Gelatin nanoparticles loaded with allicin could be used in cancer therapy due to the anticancer activity of allicin [332]. The strong antibacterial activity of biocomposites [chitosan/polyvinyl alcohol (PVA)] doped with allicin has been noticed. The long-term antibacterial impact makes allicin a perspective material for medical purposes as a tissue engineering and wound dressing material [333, 334].

\section{The Effect of Modifiers on Certain Biopolymers}

The modification of biopolymers is one of the basic steps in their processing. It helps to suit the biopolymers to certain applications. The aim of the modification is based on changing, improving, or/and creating new properties of the materials. The below table summarizes the modification effects of biopolymers caused by plant-based modifiers (Table 1 ).

\section{Conclusions}

This literature overview shows a new direction in the development of natural modifying substances with biocidal properties. The compounds contained in plants are an undoubtedly competitive group of natural modifiers because the

Table 1 The effectiveness of the biopolymers modification by certain natural additives

\begin{tabular}{|c|c|c|}
\hline Modifier & Material & Modification effects \\
\hline Lignin & PLA & Enhanced thermal resistance [335] \\
\hline Caffeic acid, gallic acid & Gelatin & Increased mechanical and antioxidant properties [336] \\
\hline Vanillic acid & PLA & Improved resistance on the photooxidative degradation $[113,337]$ \\
\hline Silymarin & PLA/PHB blends & Enhanced resistance on thermo-oxidative degradation [119] \\
\hline Resveratrol & PLA & Improved photo-oxidative and thermal stability [127] \\
\hline Hesperidin & PLA, PHA & Improved oxidation resistance [148] \\
\hline Apigenin & Starch & Decreased digestion rate of and improved thermal stability [165] \\
\hline $\begin{array}{l}\text { Kaempferol, myricetin, } \\
\text { quercetin }\end{array}$ & Chitosan & $\begin{array}{l}\text { Improved mechanical properties, reduced oxygen and water vapor permeability, } \\
\text { decreased UV light transmittance [205] }\end{array}$ \\
\hline \multirow[t]{5}{*}{ Quercetin } & Gelatin & $\begin{array}{l}\text { Increased mechanical properties and decreased swelling degree, improved the UV-light } \\
\text { absorption }[336,338]\end{array}$ \\
\hline & Chitosan & Reduced transparency and altered tint (to green one) [189] \\
\hline & Starch & Elevated thermal stability [196] \\
\hline & PLA/PEG blends & $\begin{array}{l}\text { Enhanced mechanical and thermal properties, changed colour and reduced transparency } \\
\text { [194] }\end{array}$ \\
\hline & PLA & Improved resistance on the photooxidative degradation [337] \\
\hline \multirow[t]{2}{*}{ Blackcurrant } & Starch & Altered colour and physicochemical characteristics [245] \\
\hline & Gelatin & Increased hardness and brittleness of polymer [246] \\
\hline \multirow[t]{5}{*}{ Tannic acid } & Zein & Changed shape of zein molecule which affects wettability changes [267] \\
\hline & Gelatin & $\begin{array}{l}\text { Improved mechanical properties, increased compatibility between polymer matrix and } \\
\text { additives modified with tannic acid, improved antioxidant activity, stability, transpar- } \\
\text { ency, and antibacterial properties }[263,270,339]\end{array}$ \\
\hline & Gelatin/silver nanoparticles & Synergistically increased antibacterial properties [271] \\
\hline & Chitosan & $\begin{array}{l}\text { Improved transparency, antibacterial properties; increased tensile strength and decreased } \\
\text { solubility of the material, affected synergistically on plasticizer contained in the mate- } \\
\text { rial }[272,340]\end{array}$ \\
\hline & PLA/filler & $\begin{array}{l}\text { Improved adhesion between polymer matrix and filler and greater dispersion of filler in } \\
\text { the matrix }[273,274]\end{array}$ \\
\hline Betulinic acid & PEG & Changed physical structure [341] \\
\hline Lapachol & PLA & Increased thermal durability and biodegradability [311] \\
\hline \multirow[t]{2}{*}{ Allicin } & Chitosan & Increased water solubility and changed colour [328] \\
\hline & Chitosan/PVA blend & Decreased hydrophilicity, increased porosity and changed microstructure [333] \\
\hline
\end{tabular}


effects of their antimicrobial activities are comparable to those of some synthetic biocides. In some cases, the natural compounds exhibit stronger biocidal activity. This fact makes them an interesting alternative for synthetic modifiers. Non-toxicity and complete biodegradability are some of their unquestionable advantages. Further development of natural modifiers and focus on biocidal properties of polymer materials are expected. Those expectations are justified due to the current pandemic conditions and the necessity of the elongated service life of the biocomposites. The biodegradability of polymer materials and their modifiers is crucial. Hence, the environmentally friendly and non-toxic modifiers are in constant search.

Funding No funding was received for conducting this study.

Data Availability Data is contained within the article.

\section{Declarations}

Conflict of interest The authors have no conflicts of interest to declare that are relevant to the content of this article.

Open Access This article is licensed under a Creative Commons Attribution 4.0 International License, which permits use, sharing, adaptation, distribution and reproduction in any medium or format, as long as you give appropriate credit to the original author(s) and the source, provide a link to the Creative Commons licence, and indicate if changes were made. The images or other third party material in this article are included in the article's Creative Commons licence, unless indicated otherwise in a credit line to the material. If material is not included in the article's Creative Commons licence and your intended use is not permitted by statutory regulation or exceeds the permitted use, you will need to obtain permission directly from the copyright holder. To view a copy of this licence, visit http://creativecommons.org/licenses/by/4.0/.

\section{References}

1. PN-EN ISO 1040:2006, Chemiczne środki dezynfekcyjne i antyseptyczne-Ilościowa zawiesinowa metoda określania podstawowego działania bakteriobójczego chemicznych środków dezynfekcyjnych i antyseptycznych-Metoda badania i wymagania (faza 1)

2. Agarwal C, Csóka L (2019) Chapter 6-surface-modified cellulose in biomedical engineering. In: Grumezescu V, Grumezescu AM (eds) Materials for biomedical engineering. Elsevier, Amsterdam, pp 215-261

3. Stepczyńska M (2014) Research of biocidal effect of corona discharges on poly(lactic acid) packaging films. J Food Eng 126:56-61. https://doi.org/10.1016/j.jfoodeng.2013.10.038

4. Stepczyńska M, Walczak M, Żenkiewicz M (2013) Effect of corona treatment on the mortality rate of bacterial strains. Przem Chem 92:710-714

5. Rozporządzenie Parlamentu Europejskiego i Rady (UE) nr 528/2012 z dnia 22 maja 2012 r. W sprawie udostępniania na rynku i stosowania produktów biobójczych
6. Stepczyńska M (2019) Chapter 7-modification of biodegradable materials by natural biocidal agents. In: Grumezescu V, Grumezescu AM (eds) Materials for biomedical engineering. Elsevier, Amsterdam, pp 263-279

7. Stepczyńska M (2016) Surface modification by low temperature plasma: sterilization of biodegradable materials. Plasma Process Polym 13:1080-1088. https://doi.org/10.1002/ppap.201600051

8. Petrozolin-Skowrońska B (1996) Encyklopedia Popularna PWN. Wydawnictwo Naukowe PWN, Warszawa

9. Bahl S, Dolma J, Jyot Singh J, Sehgal S (2021) Biodegradation of plastics: a state of the art review. Mater Today Proc 39:31-34. https://doi.org/10.1016/j.matpr.2020.06.096

10. Ekiert M, Mlyniec A, Uhl T (2015) The influence of degradation on the viscosity and molecular mass of poly(lactide acid) biopolymer. Diagnostyka 16:63-70

11. Ilyas RA, Sapuan SM (2020) Biopolymers and biocomposites: chemistry and technology. Curr Anal Chem 16:500-503. https:// doi.org/10.2174/157341101605200603095311

12. Price S, Kuzhiumparambil U, Pernice M, Ralph PJ (2020) Cyanobacterial polyhydroxybutyrate for sustainable bioplastic production: critical review and perspectives. J Environ Chem Eng 8:104007. https://doi.org/10.1016/j.jece.2020.104007

13. Chawla S, Kanatt S, Sharma AK (2015) Chitosan. pp 219-246. https://doi.org/10.1007/978-3-319-16298-0_13

14. Bakshi PS, Selvakumar D, Kadirvelu K, Kumar NS (2020) Chitosan as an environment friendly biomaterial-a review on recent modifications and applications. Int J Biol Macromol 150:10721083. https://doi.org/10.1016/j.ijbiomac.2019.10.113

15. Rinaudo M (2006) Chitin and chitosan: properties and applications. Prog Polym Sci 31:603-632. https://doi.org/10.1016/j. progpolymsci.2006.06.001

16. Bagnowska A, Krala L, Nowak A, Oracz J (2014) Antioxidant properties of chitosan in sausages without nitrate (III) added. Żywność Nauka Technologia Jakość 4:173-187. https://doi.org/ 10.15193/ZNTJ/2014/95/173-187

17. Ostrowska-Czubenko J, Pieróg M, Gierszewska M (2016) Modification of chitosan: a concise overview. Wiad Chem 70:657-679

18. Pandey P, Verma M, De N (2018) Chitosan in agricultural context-a review. Bull Environ Pharmacol Life Sci 7:87-96

19. Hafdani FN, Sadeghinia N (2011) A review on application of chitosan as a natural antimicrobial. Int J Pharmacol Pharm Sci 5:46-50

20. Jianglian D, Shaoying Z (2013) Application of chitosan based coating in fruit and vegetable preservation: a review. J Food Process Technol 4:227

21. Venkatesan J, Kim S-K (2010) Chitosan composites for bone tissue engineering—an overview. Mar Drugs 8:2252-2266. https:// doi.org/10.3390/md8082252

22. Lu D, Xiao C, Xu S (2009) Starch-based completely biodegradable polymer materials. EXPRESS Polym Lett 3:366-375. https:// doi.org/10.3144/expresspolymlett.2009.46

23. Sybis M, Konował E (2020) Effect of biopolymer based admixtures on selected properties of cement mortars. Przegląd Budowlany 91:39-43

24. Odeniyi MA, Omoteso OA, Adepoju AO, Jaiyeoba KT (2018) Starch nanoparticles in drug delivery: a review. Polim Med 48:41-45. https://doi.org/10.17219/pim/99993

25. Sionkowska A, Lewandowska K (2016) Biopolymers. Toruń

26. Bastioli C (2002) Starch—polymer composites. In: Scott G (ed) Degradable polymers: principles and applications. Springer Netherlands, Dordrecht, pp 133-161

27. Leszczynski W (2004) Skrobia - surowiec przemysłowy, budowa i właściwości. Zesz Probl Postępów Nauk Rol 500:69-98

28. Syafiq R, Sapuan SM, Zuhri MYM et al (2020) Antimicrobial activities of starch-based biopolymers and biocomposites 
incorporated with plant essential oils: a review. Polymers 12:2403. https://doi.org/10.3390/polym12102403

29. Tesfaye T, Gibril M, Sithole B et al (2018) Valorisation of avocado seeds: extraction and characterisation of starch for textile applications. Clean Technol Environ Policy 20:2135-2154. https://doi.org/10.1007/s10098-018-1597-0

30. Jeong H, Baek S, Han S et al (2018) Novel eco-friendly starch paper for use in flexible, transparent, and disposable organic electronics. Adv Funct Mater 28:1704433. https://doi.org/10.1002/ adfm. 201704433

31. Lam CXF, Mo XM, Teoh SH, Hutmacher DW (2002) Scaffold development using 3D printing with a starch-based polymer. Mater Sci Eng C 20:49-56. https://doi.org/10.1016/S09284931(02)00012-7

32. Xia Y, Gao W, Wang H et al (2013) Characterization of tradition Chinese medicine (TCM) starch for potential cosmetics industry application. Starch Stärke 65:367-373. https://doi.org/10.1002/ star.201200153

33. Egharevba HO (2019) Chemical properties of starch and its application in the food industry. IntechOpen, London

34. Singh N, Singh S, Kaur A, Bakshi MS (2012) Chapter 10zein: structure, production, film properties and applications. In: Natural polymers. Royal Society of Chemistry, Cambridge, pp 204-218

35. Menezes J, Athmaselvi KA (2018) Chapter 5-report on edible films and coatings. In: Grumezescu AM, Holban AM (eds) Food packaging and preservation. Academic Press, London, pp 177-212

36. Dickey LC, Parris N, Craig JC, Kurantz MJ (2001) Ethanolic extraction of zein from maize. Ind Crops Prod 1:67-76

37. Luo Y, Wang T (2016) Chapter 9-pharmaceutical and cosmetic applications of protein by-products. In: Singh Dhillon G (ed) Protein byproducts. Academic Press, London, pp 147-160

38. Sharif N, Fabra MJ, López-Rubio A (2019) 9-nanostructures of zein for encapsulation of food ingredients. In: Jafari SM (ed) Biopolymer nanostructures for food encapsulation purposes. Academic Press, London, pp 217-245

39. Agyei D, Pan S, Acquah C, Danquah MK (2017) Chapter 3-bioactivity profiling of peptides from food proteins. In: Grumezescu AM, Holban AM (eds) Soft chemistry and food fermentation. Academic Press, London, pp 49-77

40. Elzoghby AO, Elgohary MM, Kamel NM (2015) Chapter 6implications of protein- and peptide-based nanoparticles as potential vehicles for anticancer drugs. In: Donev R (ed) Advances in protein chemistry and structural biology. Academic Press, London, pp 169-221

41. Paliwal R, Palakurthi S (2014) Zein in controlled drug delivery and tissue engineering. J Control Release 189:108-122. https:// doi.org/10.1016/j.jconrel.2014.06.036

42. Lorenzo G, Sosa M, Califano A (2018) Chapter 15-alternative proteins and pseudocereals in the development of gluten-free pasta. In: Holban AM, Grumezescu AM (eds) Alternative and replacement foods. Academic Press, London, pp 433-458

43. Arvanitoyannis IS, Dionisopoulou NK (2010) Chapter 15-irradiation of edible films of plant and animal origin. In: Arvanitoyannis IS (ed) Irradiation of food commodities. Academic Press, Boston, pp 609-634

44. Gonçalves J, Torres N, Silva S et al (2020) Zein impart hydrophobic and antimicrobial properties to cotton textiles. React Funct Polym 154:104664. https://doi.org/10.1016/j.reactfunctpolym. 2020.104664

45. Padua GW, Guardiola LV (2015) Chapter 1-microcapsules produced from zein. In: Sagis LMC (ed) Microencapsulation and microspheres for food applications. Academic Press, San Diego, pp 3-20
46. Zeng W, Li Y, Wang Y, Cao Y (2019) Tissue engineering of blood vessels. In: Reis RL (ed) Encyclopedia of tissue engineering and regenerative medicine. Academic Press, Oxford, pp 413-424

47. Meng Y, Cloutier S (2014) Chapter 20-gelatin and other proteins for microencapsulation. In: Gaonkar AG, Vasisht N, Khare AR, Sobel R (eds) Microencapsulation in the food industry. Academic Press, San Diego, pp 227-239

48. Karim A, Bhat R (2009) Fish gelatin: properties, challenges, and prospects as an alternative to mammalian gelatins. Food Hydrocoll 23:563-576. https://doi.org/10.1016/j.foodhyd.2008.07.002

49. Siburian WZ, Rochima E, Andriani Y, Praseptiangga D (2020) Fish gelatin (definition, manufacture, analysis of quality characteristics, and application): a review. Int J Fish Aquat Stud 8:90-95

50. Schrieber R, Gareis H (2007) Gelatine handbook: theory and industrial practice. Wiley, Hoboken

51. Huang T, Tu Z, Shangguan X et al (2019) Fish gelatin modifications: a comprehensive review. Trends Food Sci Technol 86:260-269. https://doi.org/10.1016/j.tifs.2019.02.048

52. Bello AB, Kim D, Kim D et al (2020) Engineering and functionalization of gelatin biomaterials: from cell culture to medical applications. Tissue Eng B 26:164-180. https://doi.org/10.1089/ ten.teb.2019.0256

53. Nilforoushzadeh MA, Amirkhani MA, Zarrintaj P et al (2018) Skin care and rejuvenation by cosmeceutical facial mask. J Cosmet Dermatol 17:693-702. https://doi.org/10.1111/jocd.12730

54. Mrázek P, Gál R, Mokrejš P et al (2020) Thermal stability of prepared chicken feet gelatine gel in comparison with commercial gelatines. Potravinárstvo Slovak J Food Sci 14:535-543

55. Gómez-Guillén MC, Giménez B, López-Caballero ME, Montero MP (2011) Functional and bioactive properties of collagen and gelatin from alternative sources: a review. Food Hydrocoll 25:1813-1827. https://doi.org/10.1016/j.foodhyd.2011.02.007

56. Calixto S, Ganzherli N, Gulyaev S, Figueroa-Gerstenmaier S (2018) Gelatin as a photosensitive material. Molecules 23:2064. https://doi.org/10.3390/molecules23082064

57. Tiyyagura HR, Fuchs-Godec R, Gorgieva S et al (2018) Biomimetic gelatine coating for less-corrosive and surface bioactive Mg-9Al-1Zn alloys. J Mater Res 33:1449-1462. https://doi.org/ 10.1557/jmr.2018.65

58. Maternaghan T (1994) Use of monosize dispersions in silver halide photographic emulsions. In: Technological applications of dispersions. CRC Press, Boca Raton

59. Alrefaey HMA, Abdel-Rahman MA, Hassan SE-D et al (2021) Sequential optimization of the fermentation factors with integrating seed culture adaptation for increased biorefinery of beet molasses to lactic acid. Biomass Convers Biorefin 11:1013-1028. https://doi.org/10.1007/s13399-020-00773-3

60. Liang S, McDonald AG, Coats ER (2014) Lactic acid production with undefined mixed culture fermentation of potato peel waste. Waste Manag 34:2022-2027. https://doi.org/10.1016/j.wasman. 2014.07.009

61. Stepczyńska M (2012) Effects of corona treatment on the properties of the surface layer of polylactide. Poznan University of Technology

62. Zahari SMSNS, Mansor MH, Azman HH, Rosli D (2020) Uncatalysed polycondensation of lactic acid to polylactic acid under microwave irradiation: effect of microwave power. J Phys Conf Ser 1551:012001. https://doi.org/10.1088/1742-6596/1551/1/ 012001

63. Boonpavanitchakul K, Jarussophon S, Pimpha N et al (2019) Silk sericin as a bio-initiator for grafting from synthesis of polylactide via ring-opening polymerization. Eur Polym J 121:109265. https://doi.org/10.1016/j.eurpolymj.2019.109265 
64. Su S, Kopitzky R, Tolga S, Kabasci S (2019) Polylactide (PLA) and its blends with poly(butylene succinate) (PBS): a brief review. Polymers 11:1193. https://doi.org/10.3390/polym11071 193

65. Groot W, van Krieken J, Sliekersl O, de Vos S (2010) Production and purification of lactic acid and lactide. In: Poly(lactic acid). Wiley, Hoboken, pp 1-18

66. Dörr D, Standau T, Murillo Castellón S et al (2020) Rheology in the presence of carbon dioxide $\left(\mathrm{CO}_{2}\right)$ to study the melt behavior of chemically modified polylactide (PLA). Polymers 12:1108. https://doi.org/10.3390/polym12051108

67. Abbott S (2010) Chemical compatibility of poly(lactic acid): a practical framework using hansen solubility parameters. In: Poly(lactic acid): synthesis, structures, properties, processing, and applications. Wiley, Hoboken, pp 83-95

68. Albertsson A-C, Varma IK, Lochab B et al (2010) Design and synthesis of different types of poly(lactic acid). In: Poly(lactic acid). Wiley, Hoboken, pp 43-58

69. Nam HC, Park WH (2020) Eco-friendly poly(lactic acid) microbeads for cosmetics via melt electrospraying. Int J Biol Macromol 157:734-742. https://doi.org/10.1016/j.ijbiomac. 2019.11.240

70. Mader M, Jérôme V, Freitag R et al (2018) Ultraporous, compressible, wettable polylactide/polycaprolactone sponges for tissue engineering. Biomacromol 19:1663-1673. https://doi. org/10.1021/acs.biomac.8b00434

71. Prus-Walendziak W, Kozlowska J (2021) Design of sodium alginate/gelatin-based emulsion film fused with polylactide microparticles charged with plant extract. Materials 14:745. https://doi.org/10.3390/ma14040745

72. Wu D-Y, Wang S-S, Wu C-S (2020) Antibacterial properties and cytocompatibility of biobased nanofibers of fish scale gelatine, modified polylactide, and freshwater clam shell. Int J Biol Macromol 165:1219-1228. https://doi.org/10.1016/j.ijbiomac.2020. 10.002

73. Obuchi S, Ogawa S (2010) Packaging and other commercial applications. In: Poly(lactic acid). Wiley, Hoboken, pp 457-467

74. Rydz J, Adamus G, Wolna-Stypka K et al (2013) Degradation of polylactide in paraffin and selected protic media. Polym Degrad Stab 98:316-324. https://doi.org/10.1016/j.polymdegradstab. 2012.09.010

75. Żenkiewicz M, Richert J, Rytlewski P et al (2009) Characterisation of multi-extruded poly(lactic acid). Polym Test 28:412-418. https://doi.org/10.1016/j.polymertesting.2009.01.012

76. Mochizuki M (2010) Textile applications. In: Poly(lactic acid). Wiley, Hoboken, pp 469-476

77. Hiraishi A (2010) Environmental applications. In: Poly(lactic acid). Wiley, Hoboken, pp 477-486

78. Müller-Santos M, Koskimäki JJ, Alves LPS et al (2021) The protective role of PHB and its degradation products against stress situations in bacteria. FEMS Microbiol Rev. https://doi.org/10. 1093/femsre/fuaa058

79. Sirohi R, Lee JS, Yu BS et al (2021) Sustainable production of polyhydroxybutyrate from autotrophs using $\mathrm{CO}_{2}$ as feedstock: challenges and opportunities. Bioresour Technol 341:125751. https://doi.org/10.1016/j.biortech.2021.125751

80. Sirohi R, Prakash Pandey J, Kumar Gaur V et al (2020) Critical overview of biomass feedstocks as sustainable substrates for the production of polyhydroxybutyrate (PHB). Bioresour Technol 311:123536. https://doi.org/10.1016/j.biortech.2020.123536

81. Anbukarasu P, Sauvageau D, Elias A (2015) Tuning the properties of polyhydroxybutyrate films using acetic acid via solvent casting. Sci Rep 5:17884. https://doi.org/10.1038/srep17884

82. Narayanan M, Kandasamy G, Murali P et al (2021) Optimization and production of polyhydroxybutyrate from sludge by Bacillus cereus categorized through FT-IR and NMR analyses. J Environ Chem Eng 9:104908. https://doi.org/10.1016/j.jece.2020.104908

83. Ansari S, Fatma T (2016) Cyanobacterial polyhydroxybutyrate (PHB): screening, optimization and characterization. PLoS ONE 11:e0158168. https://doi.org/10.1371/journal.pone.0158168

84. Almenar E, Auras R (2010) Permeation, sorption, and diffusion in poly(lactic acid). In: Poly(lactic acid). Wiley, Hoboken, pp 155-179

85. Kavitha G, Rengasamy R, Inbakandan D (2018) Polyhydroxybutyrate production from marine source and its application. Int $\mathrm{J}$ Biol Macromol 111:102-108. https://doi.org/10.1016/j.ijbiomac. 2017.12.155

86. Matias F, Brandt CA, da Silva ES, de Andrade Rodrigues MF (2017) Polyhydroxybutyrate and polyhydroxydodecanoate produced by Burkholderia contaminans IPT553. J Appl Microbiol 123:124-133. https://doi.org/10.1111/jam.13469

87. Rech CR, da Silva Brabes KC, Bagnara e Silva BE et al (2020) Biodegradation of eugenol-loaded polyhydroxybutyrate films in different soil types. Case Stud Chem Environ Eng 2:100014. https://doi.org/10.1016/j.cscee.2020.100014

88. Zdunczyk Z (2001) Przeciwodzywcze i-lub prozdrowotne wlasciwosci wtornych metabolitow roslin. Żywność Nauka Technol Jakość Supl 8:150-163

89. Efenberger-Szmechtyk M, Nowak A (2018) Ekstrakty bogate w polifenole naturalne konserwanty produktów mięsnych. Przem Spoż 72:28-33. https://doi.org/10.15199/65.2018.5.3

90. Krzyżek P (2016) Polyphenols in the treatment of diseases caused by Helicobacter pylori. Postępy Fitoter 18:24-30

91. Teplova VV, Isakova EP, Klein OI et al (2018) Natural polyphenols: biological activity, pharmacological potential, means of metabolic engineering (review). Appl Biochem Microbiol 54:221-237. https://doi.org/10.1134/S0003683818030146

92. Ferrazzano GF, Amato I, Ingenito A et al (2011) Plant polyphenols and their anti-cariogenic properties: a review. Molecules 16:1486-1507. https://doi.org/10.3390/molecules16021486

93. Holmbom B, Willför S, Hemming J et al (2007) Knots in trees: a rich source of bioactive polyphenols. In: Argyropoulos D (ed) ACS symposium series. American Chemical Society, Washington, pp 350-362

94. Larif M, Zarrouk A, Soulaymani A, Elmidaoui A (2013) New innovation in order to recover the polyphenols of olive mill wastewater extracts for use as a biopesticide against the Euphyllura olivina and Aphis citricola. Res Chem Intermed 39:43034313. https://doi.org/10.1007/s11164-012-0947-5

95. Solyenova E, Nikolaevna Velichkovska L (2017) Flavonoids. Prospects of their use in antimicrobial therapy. Acta Medica Eurasica 3:50-57

96. Smirnov O, Kosyk O (2011) Flavonoids rutin and quercetin. Biosynthesis, structure, functions. Visnyk Lviv Univ Ser Biol 56:3-11

97. Jasinski M, Mazurkiewicz E, Rodziewicz P, Figlerowicz M (2009) Flavonoids' structure, properties and particular function for legume plants. Biotechnologia 85:81-94

98. Kosiorek A, Oszmiański J, Golański J (2013) Rationale for the use of plant polyphenols as antiplatelet nutraceuticals. Postępy Fitoter 108-117

99. Khan N, Al Daghri N, Al Ajlan A, Alokail M (2014) The use of natural and derived sources of flavonoids and antioxidants in Saudi Arabia. Integr Food Nutr Metab 1:100-106. https://doi. org/10.15761/IFNM.1000109

100. Kiewlicz J (2013) Długołańcuchowe estry kwasów fenolowych jako wielofunkcyjne składniki kształtujące jakość wyrobów kosmetycznych. Rozprawa doktorska, Uniwersytet Ekonomiczny w Poznaniu

101. Gniazdowska A, Oracz K, Bogatek R (2004) Allelopathy - new interpretations of plant - plant interactions. Kosmos 53:207-217 
102. Lubsandorzhieva PB (2010) The content of phenolic acids in multy-componental herb teas. Acta Biomedica Scientifica 3:241-244

103. Robbins RJ (2003) Phenolic acids in foods: an overview of analytical methodology. J Agric Food Chem 51:2866-2887. https:// doi.org/10.1021/jf026182t

104. Paszkiewicz M, Budzyńska A, Rozalska B, Sadowska B (2012) The immunomodulatory role of plant polyphenols. Adv Hyg Exp Med 66:637-646. https://doi.org/10.5604/17322693.1009908

105. Parus A (2013) Antioxidant and pharmacological properties of phenolic acids. Postępy Fitoterapii 1:48-54

106. Moniruzzaman M, Yung An C, Rao PV et al (2014) Identification of phenolic acids and flavonoids in monofloral honey from Bangladesh by high performance liquid chromatography: determination of antioxidant capacity. BioMed Res Int 2014:e737490. https://doi.org/10.1155/2014/737490

107. Lee SJ, Kang M-S, Oh J-S et al (2013) Caffeic acid-conjugated chitosan derivatives and their anti-tumor activity. Arch Pharm Res 36:1437-1446. https://doi.org/10.1007/s12272-013-0139-x

108. Moreno MA, Orqueda ME, Gómez-Mascaraque LG et al (2019) Crosslinked electrospun zein-based food packaging coatings containing bioactive chilto fruit extracts. Food Hydrocoll 95:496505. https://doi.org/10.1016/j.foodhyd.2019.05.001

109. Skogsberg M (2014) Polylactide with natural antioxidants: active packaging films and stability effects on the polymer. School of Chemical Science and Engineering (CHE), Stockholm

110. Kuntzler SG, de Almeida ACA, Costa JAV, de Morais MG (2018) Polyhydroxybutyrate and phenolic compounds microalgae electrospun nanofibers: a novel nanomaterial with antibacterial activity. Int J Biol Macromol 113:1008-1014. https://doi.org/ 10.1016/j.ijbiomac.2018.03.002

111. Neo YP, Ray S, Jin J et al (2013) Encapsulation of food grade antioxidant in natural biopolymer by electrospinning technique: a physicochemical study based on zein-gallic acid system. Food Chem 136:1013-1021. https://doi.org/10.1016/j.foodchem.2012. 09.010

112. Vishnu KV, Chatterjee NS, Ajeeshkumar KK et al (2017) Microencapsulation of sardine oil: application of vanillic acid grafted chitosan as a bio-functional wall material. Carbohydr Polym 174:540-548. https://doi.org/10.1016/j.carbpol.2017.06.076

113. Dintcheva NT, Arrigo R, Baiamonte M et al (2017) Concentration-dependent anti-/pro-oxidant activity of natural phenolic compounds in bio-polyesters. Polym Degrad Stab 142:21-28. https://doi.org/10.1016/j.polymdegradstab.2017.05.022

114. Thi TH, Matsusaki M, Akashi M (2009) Photoreactive polylactide nanoparticles by the terminal conjugation of biobased caffeic acid. Langmuir 25:10567-10574. https://doi.org/10.1021/la901 353e

115. Bento-Silva A, Koistinen VM, Mena P et al (2020) Factors affecting intake, metabolism and health benefits of phenolic acids: do we understand individual variability? Eur J Nutr 59:1275-1293. https://doi.org/10.1007/s00394-019-01987-6

116. Kosman V, Pozharitskaya O, Shikov A, Makarov V (2014) Lignans of oil extract from Schisandra chinensis Turcz. (Baill.) seeds. Chem Plant Raw Mater. https://doi.org/10.14258/jcprm. 201404319

117. Lam P-L, Gambari R, Yip J et al (2012) Development of phyllanthin containing microcapsules and their improved biological activity towards skin cells and Staphylococcus aureus. Bioorg Med Chem Lett 22:468-471. https://doi.org/10.1016/j.bmcl. 2011.10.097

118. Shankar S, Rhim J-W (2018) Bionanocomposite films for food packaging applications. In: Reference module in food science. Elsevier, pp 1-10
119. Olejnik O, Masek A (2020) Effect of silymarin on thermooxidative degradation of PLA/PHB blends. Inż Mater. https://doi.org/ 10.15199/28.2020.3.3

120. Mrduljas N, Kresic G, Bilušić T (2017) Polyphenols: food sources and health benefits. In: Hueda MC (ed) Functional food-improve health through adequate food. IntechOpen, London, pp 23-41

121. Shen T, Wang X-N, Lou H-X (2009) Natural stilbenes: an overview. Nat Prod Rep 26:916-935. https://doi.org/10.1039/B9059 $60 \mathrm{~A}$

122. Wei Y, Yu Z, Lin K et al (2019) Fabrication and characterization of resveratrol loaded zein-propylene glycol alginate-rhamnolipid composite nanoparticles: physicochemical stability, formation mechanism and in vitro digestion. Food Hydrocoll 95:336-348. https://doi.org/10.1016/j.foodhyd.2019.04.048

123. Khan MA, Yue C, Fang Z et al (2019) Alginate/chitosan-coated zein nanoparticles for the delivery of resveratrol. J Food Eng 258:45-53. https://doi.org/10.1016/j.jfoodeng.2019.04.010

124. Yu F, Li M, Yuan Z et al (2018) Mechanism research on a bioactive resveratrol-PLA-gelatin porous nano-scaffold in promoting the repair of cartilage defect. Int J Nanomed 13:7845-7858. https://doi.org/10.2147/IJN.S181855

125. Li L, Wang $H$, Chen $M$ et al (2020) Gelatin/zein fiber mats encapsulated with resveratrol: kinetics, antibacterial activity and application for pork preservation. Food Hydrocoll 101:105577. https://doi.org/10.1016/j.foodhyd.2019.105577

126. Huang S, Tu Z, Sha X et al (2021) Fabrication and performance evaluation of pectin-fish gelatin-resveratrol preservative films. Food Chem 361:129832. https://doi.org/10.1016/j.foodchem. 2021.129832

127. Agustin-Salazar S, Gamez-Meza N, Medina-Juàrez LÀ et al (2014) From nutraceutics to materials: effect of resveratrol on the stability of polylactide. ACS Sustain Chem Eng 2:1534-1542. https://doi.org/10.1021/sc5002337

128. Dhanapal J, Balaraman Ravindrran M (2018) Chitosan/ poly(lactic acid)-coated piceatannol nanoparticles exert an in vitro apoptosis activity on liver, lung and breast cancer cell lines. Artif Cells Nanomed Biotechnol 46:274-282. https://doi. org/10.1080/21691401.2017.1422130

129. Algandaby MM, Al-Sawahli MM (2021) Augmentation of antiproliferative, pro-apoptotic and oxidant profiles induced by piceatannol in human breast carcinoma MCF-7 cells using zein nanostructures. Biomed Pharmacother 138:111409. https://doi. org/10.1016/j.biopha.2021.111409

130. Biesalski H-K, Dragsted LO, Elmadfa I et al (2009) Bioactive compounds: definition and assessment of activity. Nutrition 25:1202-1205. https://doi.org/10.1016/j.nut.2009.04.023

131. Gómez-Betancur I, Pereañez JA, Patiño AC, Benjumea D (2016) Inhibitory effect of pinostrobin from Renealmia alpinia, on the enzymatic and biological activities of a PLA2. Int J Biol Macromol 89:35-42. https://doi.org/10.1016/j.ijbiomac.2016.04.042

132. Junior WAR, Gomes DB, Zanchet B et al (2017) Antiproliferative effects of pinostrobin and 5,6-dehydrokavain isolated from leaves of Alpinia zerumbet. Rev Bras Farmacogn 27:592-598. https:// doi.org/10.1016/j.bjp.2017.05.007

133. Suriyatem R, Auras RA, Rachtanapun C, Rachtanapun P (2018) Biodegradable rice starch/carboxymethyl chitosan films with added propolis extract for potential use as active food packaging. Polymers 10:954. https://doi.org/10.3390/polym10090954

134. Jaudan A, Sharma S, Malek SNA, Dixit A (2018) Induction of apoptosis by pinostrobin in human cervical cancer cells: possible mechanism of action. PLoS ONE 13:1-23. https://doi.org/10. 1371/journal.pone.0191523

135. Wiyono L, Rahmawanti R, Cristie Edina B et al (2020) Isolation, synthesis nanoparticle, and in-vitro test of pinostrobin from 
kaempferia pandurata on MCF-7 and MDAMB-231 breast cancer cell. Res J Pharm Technol. https://doi.org/10.5958/0974-360X. 2020.00497.7

136. Bodakowska-Boczniewicz J, Garncarek Z (2016) The importance of bitter bioactive food components in the prevention of disease. Eng Sci Technol 4:9-25. https://doi.org/10.15611/nit.2016.4.01

137. Sivtseva O, Oganesyan E, Andreeva O, Mogilenko T (2020) Qualitative and quantitative determination of flavonoids in Citrus limonia (L.). Int Res J 100:98-101

138. Błazińska P, Sykuła A (2018) Właściwości i zastosowanie flawanonów. In: Kępczak N (ed) Książka Artykułów Konferencji Naukowej "Wiedza Kluczem do Sukcesu 2018”. Wydawnictwo Fundacji Promovendi, Łódź, pp 5-11

139. Tutunchi H, Naeini F, Ostadrahimi A, Hosseinzadeh-Attar MJ (2020) Naringenin, a flavanone with antiviral and antiinflammatory effects: a promising treatment strategy against COVID-19. Phytother Res 34:3137-3147. https://doi.org/10. 1002/ptr.6781

140. Kumar SP, Birundha K, Kaveri K, Devi KTR (2015) Antioxidant studies of chitosan nanoparticles containing naringenin and their cytotoxicity effects in lung cancer cells. Int J Biol Macromol 78:87-95. https://doi.org/10.1016/j.ijbiomac.2015. 03.045

141. Moeiniafshari A-A, Zarrabi A, Bordbar A-K (2015) Exploring the interaction of naringenin with bovine beta-casein nanoparticles using spectroscopy. Food Hydrocoll 51:1-6. https://doi. org/10.1016/j.foodhyd.2015.04.036

142. Akrawi SH, Gorain B, Nair AB et al (2020) Development and optimization of naringenin-loaded chitosan-coated nanoemulsion for topical therapy in wound healing. Pharmaceutics 12:893. https://doi.org/10.3390/pharmaceutics 12090893

143. Meneguzzo F, Ciriminna R, Zabini F, Pagliaro M (2020) Review of evidence available on hesperidin-rich products as potential tools against COVID-19 and hydrodynamic cavitation-based extraction as a method of increasing their production. Processes 8:1-18. https://doi.org/10.3390/pr8050549

144. Haggag YA, El-Ashmawy NE, Okasha KM (2020) Is hesperidin essential for prophylaxis and treatment of COVID-19 Infection? Med Hypotheses 144:1-3. https://doi.org/10.1016/j. mehy.2020.109957

145. Bellavite P, Donzelli A (2020) Hesperidin and SARS-COV-2: new light on the healthy function of citrus fruits. Antioxidants 9:1-18. https://doi.org/10.3390/antiox9080742

146. Bagher Z, Ehterami A, Safdel MH et al (2020) Wound healing with alginate/chitosan hydrogel containing hesperidin in rat model. J Drug Deliv Sci Technol 55:101379. https://doi.org/ 10.1016/j.jddst.2019.101379

147. Dammak I, Lourenço RV, do Aobral PJA (2019) Active gelatin films incorporated with Pickering emulsions encapsulating hesperidin: preparation and physicochemical characterization. J Food Eng 240:9-20. https://doi.org/10.1016/j.jfoodeng.2018. 07.002

148. Masek A, Latos-Brozio M (2018) The effect of substances of plant origin on the thermal and thermo-oxidative ageing of aliphatic polyesters (PLA, PHA). Polymers 10:1252. https:// doi.org/10.3390/polym10111252

149. Salehi B, Venditti A, Sharifi-Rad M et al (2019) The therapeutic potential of apigenin. Int J Mol Sci 20:1-26. https://doi.org/ 10.3390/ijms20061305

150. Piponski M, Stoimenova TB, Topkoska M et al (2018) Development and validation of a fast and simple RP-HPLC method for the determination of diosmin and hesperidin in combined tablet dosage form. Maced J Chem Chem Eng 37:127-134. https://doi. org/10.20450/mjcce.2018.1448
151. Klimek-Szczykutowicz M, Szopa A, Ekiert H (2017) Citrus limon (lemon) - a source of raw materials with valuable cosmetic properties. Pol J Cosmetol 20:184-195

152. Popova NV, Dikhtyaryov SI, Maslova NF, Litvinenko VI (2011) Antibiotic properties of lyuteolin. Ukr Biopharm J 17:4-11

153. Brown AR, Ettefagh KA, Todd D et al (2015) A mass spectrometry-based assay for improved quantitative measurements of efflux pump inhibition. PLoS ONE 10:1-12. https://doi.org/10.1371/ journal.pone.0124814

154. Shinde P, Agraval H, Singh A et al (2019) Synthesis of luteolin loaded zein nanoparticles for targeted cancer therapy improving bioavailability and efficacy. J Drug Deliv Sci Technol 52:369378. https://doi.org/10.1016/j.jddst.2019.04.044

155. Gilani SJ, Bin-Jumah M, Rizwanullah M et al (2021) Chitosan coated luteolin nanostructured lipid carriers: optimization, in vitro-ex vivo assessments and cytotoxicity study in breast cancer cells. Coatings 11:158. https://doi.org/10.3390/coatings11 020158

156. Qing W, Wang Y, Li H et al (2017) Preparation and characterization of copolymer micelles for the solubilization and in vitro release of luteolin and luteoloside. AAPS PharmSciTech 18:2095-2101. https://doi.org/10.1208/s12249-016-0692-y

157. Chen Y-Y, Liu K, Zha X-Q et al (2021) Encapsulation of luteolin using oxidized lotus root starch nanoparticles prepared by antisolvent precipitation. Carbohydr Polym 273:118552. https://doi. org/10.1016/j.carbpol.2021.118552

158. Bi F, Qin Y, Chen D et al (2021) Development of active packaging films based on chitosan and nano-encapsulated luteolin. Int $\mathbf{J}$ Biol Macromol 182:545-553. https://doi.org/10.1016/j.ijbiomac. 2021.04.063

159. Imran M, Rauf A, Abu-Izneid T et al (2019) Luteolin, a flavonoid, as an anticancer agent: a review. Biomed Pharmacother 112:1-10. https://doi.org/10.1016/j.biopha.2019.108612

160. Tutelyan VA, Lashneva NV (2013) Biologically active substances of plant origin. Flavonols and flavones: prevalence, dietary sourses and consumption. Vopr Pitan 82:4-11

161. Poureini F, Najafpour GD, Nikzad M et al (2021) Loading of apigenin extracted from parsley leaves on colloidal core-shell nanocomposite for bioavailability enhancement. Colloids Surf Physicochem Eng Asp 625:126867. https://doi.org/10.1016/j. colsurfa.2021.126867

162. Zhang L, Li X, Wang Z (2017) Construction, in vitro release and rheological behavior of apigenin-encapsulated hexagonal liquid crystal. J Drug Deliv Sci Technol 41:475-481. https://doi.org/ 10.1016/j.jddst.2017.09.003

163. Shukla R, Kashaw SK, Jain AP, Lodhi S (2016) Fabrication of Apigenin loaded gellan gum-chitosan hydrogels (GGCHHGs) for effective diabetic wound healing. Int J Biol Macromol 91:1110-1119. https://doi.org/10.1016/j.ijbiomac.2016.06.075

164. Samadian N, Hashemi M (2018) Effects of apigenin and apigenin-loaded nanogel on induction of apoptosis in human chronic myeloid leukemia cells. Galen Med J 7:e1008. https://doi.org/10. 22086/gmj.v0i0.1008

165. LiMing Z, WenJia S, Li Z et al (2020) Digestibility of starchapigenin complex prepared by ball-milling method. Shipin Kexue Food Sci 41:64-70

166. Sharma A, Sharma P, Tuli HS, Sharma A (2018) Phytochemical and pharmacological properties of flavonols. In: Encyclopedia for life science. Wiley, Chichester, pp 1-12

167. Ramos-Pineda AM, García-Estévez I, Dueñas M, EscribanoBailón MT (2018) Effect of the addition of mannoproteins on the interaction between wine flavonols and salivary proteins. Food Chem 264:226-232. https://doi.org/10.1016/j.foodchem.2018. 04.119

168. Rolnik A, Żuchowski J, Stochmal A, Olas B (2020) Quercetin and kaempferol derivatives isolated from aerial parts of Lens 
culinaris Medik as modulators of blood platelet functions. Ind Crops Prod 152:1-8. https://doi.org/10.1016/j.indcrop.2020. 112536

169. Park K-S, Chong Y, Kim MK (2016) Myricetin: biological activity related to human health. Appl Biol Chem 59:259-269. https:// doi.org/10.1007/s13765-016-0150-2

170. Devi KP, Malar DS, Nabavi SF et al (2015) Kaempferol and inflammation: from chemistry to medicine. Pharmacol Res 99:110. https://doi.org/10.1016/j.phrs.2015.05.002

171. Du W, An Y, He X et al (2018) Protection of kaempferol on oxidative stress-induced retinal pigment epithelial cell damage. Oxid Med Cell Longev. https://doi.org/10.1155/2018/1610751

172. Ren J, Lu Y, Qian Y et al (2019) Recent progress regarding kaempferol for the treatment of various diseases (review). Exp Ther Med 18:2759-2776. https://doi.org/10.3892/etm.2019.7886

173. Yeon MJ, Lee MH, Kim DH et al (2019) Anti-inflammatory effects of kaempferol on Helicobacter pylori-induced inflammation. Biosci Biotechnol Biochem 83:166-173. https://doi.org/10. 1080/09168451.2018.1528140

174. Carrasco-Sandoval J, Aranda-Bustos M, Henríquez-Aedo K et al (2021) Bioaccessibility of different types of phenolic compounds co-encapsulated in alginate/chitosan-coated zein nanoparticles. LWT 149:112024. https://doi.org/10.1016/j.lwt.2021.112024

175. Ranjbar FE, Foroutan F, Hajian M et al (2021) Preparation and characterization of $58 \mathrm{~S}$ bioactive glass based scaffold with kaempferol-containing zein coating for bone tissue engineering. J Biomed Mater Res B 109:1259-1270. https://doi.org/10.1002/ jbm.b.34786

176. Rofeal M, El-Malek FA, Qi X (2021) In vitroassessment of green polyhydroxybutyrate/chitosan blend loaded with kaempferol nanocrystals as a potential dressing for infected wounds. Nanotechnology. https://doi.org/10.1088/1361-6528/abf7ee

177. Chuang Y-L, Fang H-W, Ajitsaria A et al (2019) Development of kaempferol-loaded gelatin nanoparticles for the treatment of corneal neovascularization in mice. Pharmaceutics 11:635. https:// doi.org/10.3390/pharmaceutics11120635

178. Ilk S, Saglam N, Özgen M (2017) Kaempferol loaded lecithin/ chitosan nanoparticles: preparation, characterization, and their potential applications as a sustainable antifungal agent. Artif Cells Nanomed Biotechnol 45:907-916. https://doi.org/10.1080/ 21691401.2016.1192040

179. Tasca F, Antiochia R (2020) Biocide activity of green quercetinmediated synthesized silver nanoparticles. Nanomaterials 10:111. https://doi.org/10.3390/nano10050909

180. Pulit J, Banach M, Szczygłowska R, Bryk M (2013) Nanosilver against fungi. Silver nanoparticles as an effective biocidal factor. Acta Biochim Pol 60:795-798

181. Wang S, Yao J, Zhou B et al (2018) Bacteriostatic effect of quercetin as an antibiotic alternative in vivo and its antibacterial mechanism in vitro. J Food Prot 81:68-78. https://doi.org/10. 4315/0362-028X.JFP-17-214

182. Li H, Wang D, Liu C et al (2019) Fabrication of stable zein nanoparticles coated with soluble soybean polysaccharide for encapsulation of quercetin. Food Hydrocoll 87:342-351. https:// doi.org/10.1016/j.foodhyd.2018.08.002

183. Ma J-J, Yu Y-G, Yin S-W et al (2018) Cellular uptake and intracellular antioxidant activity of zein/chitosan nanoparticles incorporated with quercetin. J Agric Food Chem 66:12783-12793. https://doi.org/10.1021/acs.jafc.8b04571

184. Penalva R, González-Navarro CJ, Gamazo C et al (2017) Zein nanoparticles for oral delivery of quercetin: pharmacokinetic studies and preventive anti-inflammatory effects in a mouse model of endotoxemia. Nanomed Nanotechnol Biol Med 13:103110. https://doi.org/10.1016/j.nano.2016.08.033
185. Aytac Z, Ipek S, Durgun E, Uyar T (2018) Antioxidant electrospun zein nanofibrous web encapsulating quercetin/cyclodextrin inclusion complex. J Mater Sci 53:1527-1539. https://doi.org/10. 1007/s10853-017-1580-x

186. Lightfoot Vidal S, Rojas C, Bouza Padín R et al (2016) Synthesis and characterization of polyhydroxybutyrate-co-hydroxyvalerate nanoparticles for encapsulation of quercetin. J Bioact Compat Polym 31:439-452. https://doi.org/10.1177/0883911516635839

187. Kost B, Svyntkivska M, Brzeziński M et al (2020) PLA/ $\beta$-CDbased fibres loaded with quercetin as potential antibacterial dressing materials. Colloids Surf B 190:110949. https://doi.org/ 10.1016/j.colsurfb.2020.110949

188. Arpornmaeklong P, Sareethammanuwat M, Apinyauppatham K, Boonyuen S (2021) Characteristics and biologic effects of thermosensitive quercetin-chitosan/collagen hydrogel on human periodontal ligament stem cells. J Biomed Mater Res B 109:16561670. https://doi.org/10.1002/jbm.b.34823

189. Souza MP, Vaz AFM, Silva HD et al (2015) Development and characterization of an active chitosan-based film containing quercetin. Food Bioprocess Technol 8:2183-2191. https://doi. org/10.1007/s11947-015-1580-2

190. Yadav S, Mehrotra GK, Bhartiya P et al (2020) Preparation, physicochemical and biological evaluation of quercetin based chitosan-gelatin film for food packaging. Carbohydr Polym 227:115348. https://doi.org/10.1016/j.carbpol.2019.115348

191. Benbettaïeb N, Chambin O, Karbowiak T, Debeaufort F (2016) Release behavior of quercetin from chitosan-fish gelatin edible films influenced by electron beam irradiation. Food Control 66:315-319. https://doi.org/10.1016/j.foodcont.2016.02.027

192. Tongdeesoontorn W, Mauer LJ, Wongruong S et al (2021) Antioxidant films from cassava starch/gelatin biocomposite fortified with quercetin and TBHQ and their applications in food models. Polymers 13:1117. https://doi.org/10.3390/polym 13071117

193. Benbettaïeb N, Karbowiak T, Brachais C-H, Debeaufort F (2015) Coupling tyrosol, quercetin or ferulic acid and electron beam irradiation to cross-link chitosan-gelatin films: a structurefunction approach. Eur Polym J 67:113-127. https://doi.org/10. 1016/j.eurpolymj.2015.03.060

194. Olewnik-Kruszkowska E, Gierszewska M, Richert A et al (2021) Antibacterial films based on polylactide with the addition of quercetin and poly(ethylene glycol). Materials 14:1643. https:// doi.org/10.3390/ma14071643

195. Souza MP, Vaz AFM, Correia MTS et al (2014) Quercetin-loaded lecithin/chitosan nanoparticles for functional food applications. Food Bioprocess Technol 7:1149-1159. https://doi.org/10.1007/ s11947-013-1160-2

196. Zhang L, Yang X, Li S, Gao W (2011) Preparation, physicochemical characterization and in vitro digestibility on solid complex of maize starches with quercetin. LWT Food Sci Technol 44:787-792. https://doi.org/10.1016/j.lwt.2010.09.001

197. Yashin A, Yashin Y, Xia X, Nemzer B (2017) Antioxidant activity of spices and their impact on human health: a review. Antioxidants 6:70. https://doi.org/10.3390/antiox6030070

198. Yao Y, Lin G, Xie Y et al (2014) Preformulation studies of myricetin: a natural antioxidant flavonoid. Pharmazie 69:19-26

199. Zheng A-W, Chen Y-Q, Zhao L-Q, Feng J-G (2017) Myricetin induces apoptosis and enhances chemosensitivity in ovarian cancer cells. Oncol Lett 13:4974-4978. https://doi.org/10.3892/ol. 2017.6031

200. Semwal DK, Semwal RB, Combrinck S, Viljoen A (2016) Myricetin: a dietary molecule with diverse biological activities. Nutrients 8:1-31. https://doi.org/10.3390/nu8020090

201. Yao Y, Xia M, Wang H et al (2016) Preparation and evaluation of chitosan-based nanogels/gels for oral delivery of myricetin. Eur 
J Pharm Sci 91:144-153. https://doi.org/10.1016/j.ejps.2016.06. 014

202. Wang G, Wang J-J, Tang X-J et al (2016) In vitro and in vivo evaluation of functionalized chitosan-pluronic micelles loaded with myricetin on glioblastoma cancer. Nanomed Nanotechnol Biol Med 12:1263-1278. https://doi.org/10.1016/j.nano.2016.02. 004

203. Xia W, Zheng B, Li T et al (2020) Fabrication, characterization and evaluation of myricetin adsorption onto starch nanoparticles. Carbohydr Polym 250:116848. https://doi.org/10.1016/j.carbpol. 2020.116848

204. Guo H, Chen YF, Tang Y, Qian JQ (2020) Method for enhancing bioavailability of myricetin based on self-assembly of caseinmyricetin nanomicelles. IET Nanobiotechnol 14:239-244. https://doi.org/10.1049/iet-nbt.2018.5431

205. Zhang N, Bi F, Xu F et al (2020) Structure and functional properties of active packaging films prepared by incorporating different flavonols into chitosan based matrix. Int J Biol Macromol 165:625-634. https://doi.org/10.1016/j.ijbiomac.2020.09.209

206. Naumenko V, Sorochinsky B, Kolychev V (2013) Plant isoflavones: biosynhtesis, detection and biological properties. Biotechnol Acta 6:62-78. https://doi.org/10.15407/biotech6.05.062

207. Vitale D, Piazza C, Melilli B et al (2012) Isoflavones: estrogenic activity, biological effect and bioavailability. Eur J Drug Metab Pharmacokinet. https://doi.org/10.1007/s13318-012-0112-y

208. Leis K, Kulczyńska A, Racinowski M et al (2021) Genistein-a supplement improving efficiency of the human body: a review. Sci Sports. https://doi.org/10.1016/j.scispo.2020.08.005

209. Hong H, Landauer MR, Foriska MA, Ledney GD (2006) Antibacterial activity of the soy isoflavone genistein. J Basic Microbiol 46:329-335. https://doi.org/10.1002/jobm.200510073

210. Zhao L, Wang Y, Liu J et al (2016) Protective effects of genistein and puerarin against chronic alcohol-induced liver injury in mice via antioxidant, anti-inflammatory, and anti-apoptotic mechanisms. J Agric Food Chem 64:7291-7297. https://doi.org/ 10.1021/acs.jafc.6b02907

211. Vo TS (2020) Natural products targeting FceRI receptor for antiallergic therapeutics. J Food Biochem 44:e13335. https://doi.org/ 10.1111/jfbc. 13335

212. Xiao Y, Ho C-T, Chen Y et al (2020) Synthesis, characterization, and evaluation of genistein-loaded zein/carboxymethyl chitosan nanoparticles with improved water dispersibility, enhanced antioxidant activity, and controlled release property. Foods 9:1604. https://doi.org/10.3390/foods9111604

213. Rahmani F, Karimi E, Oskoueian E (2020) Synthesis and characterisation of chitosan-encapsulated genistein: its anti-proliferative and anti-angiogenic activities. J Microencapsul 37:305-313. https://doi.org/10.1080/02652048.2020.1740804

214. Cai L, Yu R, Hao X, Ding X (2017) Folate receptor-targeted bioflavonoid genistein-loaded chitosan nanoparticles for enhanced anticancer effect in cervical cancers. Nanoscale Res Lett 12:509. https://doi.org/10.1186/s11671-017-2253-z

215. Song X, Gan K, Qin S et al (2019) Preparation and characterization of general-purpose gelatin-based co-loading flavonoids nano-core structure. Sci Rep 9:6365. https://doi.org/10.1038/ s41598-019-42909-0

216. Soleimanpour M, Tamaddon AM, Kadivar M et al (2020) Fabrication of nanostructured mesoporous starch encapsulating soyderived phytoestrogen (genistein) by well-tuned solvent exchange method. Int J Biol Macromol 159:1031-1047. https://doi.org/10. 1016/j.ijbiomac.2020.05.124

217. Ravikumara NR, Waree T, Basavaraj M (2013) Fabrication and characterization of genistein encapsulated poly $(\mathrm{d}, \mathrm{l})$ lactic acid nanoparticles for pharmaceutical application. Curr Nanosci 9:293-302. https://doi.org/10.2174/1573413711309020021
218. Ibrahim S, Sayed HM, EL-Rafei AM et al (2016) Improved genistein loading and release on electrospun chitosan nanofiber blends. J Mol Liq 223:1056-1061. https://doi.org/10.1016/j.molliq.2016.09.033

219. Vanden Braber NL, Novotny Nuñez I, Bohl L et al (2018) Soy genistein administered in soluble chitosan microcapsules maintains antioxidant activity and limits intestinal inflammation. $\mathrm{J}$ Nutr Biochem 62:50-58. https://doi.org/10.1016/j.jnutbio.2018. 08.009

220. Fujitaka Y, Hamada H, Uesugi D et al (2019) Synthesis of daidzein glycosides, $\alpha$-tocopherol glycosides, hesperetin glycosides by bioconversion and their potential for anti-allergic functionalfoods and cosmetics. Molecules 24:1-11. https://doi.org/10. 3390/molecules24162975

221. Niu Z-R, Fang L-H, Qiang G-F, Du G-H (2018) Daidzein. In: Du G-H (ed) Natural small molecule drugs from plants. Springer, Singapore, pp 31-35

222. Xu C, Xu Y, Chen M et al (2020) Soy protein adhesive with bio-based epoxidized daidzein for high strength and mildew resistance. Chem Eng J 390:1-26. https://doi.org/10.1016/j. cej.2020.124622

223. Chakravarty S, Ray S, Talapatra SN (2019) Antibacterial phytochemicals in Macrotyloma uniflorum (Lam.) Verdc. On DNA-gyrase B: an in silico study. Res J Life Sci Bioinform Pharm Chem Sci 5:221-235

224. Baraboy VA (2009) Soybean isoflavones: biological activity and application. Biotechnol Acta 2:44-54

225. Ge Y, Chen D, Xie L, Zhang R (2007) Optimized preparation of daidzein-loaded chitosan microspheres and in vivo evaluation after intramuscular injection in rats. Int $\mathbf{J}$ Pharm 338:142-151. https://doi.org/10.1016/j.ijpharm.2007.01.046

226. Tousen $\mathrm{Y}$, Abe F, Ishida $\mathrm{T}$ et al (2011) Resistant starch promotes equol production and inhibits tibial bone loss in ovariectomized mice treated with daidzein. Metabolism 60:14251432. https://doi.org/10.1016/j.metabol.2011.02.009

227. Panizzon GP, Bueno FG, Ueda-Nakamura T et al (2014) Preparation of spray-dried soy isoflavone-loaded gelatin microspheres for enhancement of dissolution: formulation, characterization and in vitro evaluation. Pharmaceutics 6:599-615. https://doi.org/10.3390/pharmaceutics6040599

228. Ma Y, Zhao X, Li J, Shen Q (2012) The comparison of different daidzein-PLGA nanoparticles in increasing its oral bioavailability. Int J Nanomed 7:559-570. https://doi.org/10.2147/IJN. S27641

229. Scheithauer EC, Li W, Ding Y et al (2015) Preparation and characterization of electrosprayed daidzein-loaded PHBV microspheres. Mater Lett 158:66-69. https://doi.org/10.1016/j. matlet.2015.05.133

230. Marini H, Polito F, Adamo EB et al (2012) Update on genistein and thyroid: an overall message of safety. Front Endocrinol 3:1-4. https://doi.org/10.3389/fendo.2012.00094

231. Muntean E, Urda C, Rezi R (2021) Isoflavones in Transylvanian soybeans genotypes. In: Proceedings of the 1st international electronic conference on agronomy. MDPI, Basel

232. Lee JH, Jeong SW, Cho YA et al (2013) Determination of the variations in levels of phenolic compounds in soybean (Glycine max Merr.) sprouts infected by anthracnose (Colletotrichum gloeosporioides). J Sci Food Agric 93:3081-3086. https://doi. org/10.1002/jsfa.6142

233. Son GH, Kim J, Muthaiya MJ et al (2011) Antimicrobial compounds profile during Cheonggukjang fermentation against Xanthomonas oryzae pv. oryzae (Xoo). J Microbiol Biotechnol 21:1147-1150. https://doi.org/10.4014/jmb.1109.09075

234. Gao X, Liu E, Zhang J et al (2019) Effects of sonication during moromi fermentation on antioxidant activities of compounds 
in raw soy sauce. LWT Food Sci Technol 116:1-8. https://doi. org/10.1016/j.lwt.2019.108605

235. Parameters of the glycitein. https://www.sigmaaldrich.com/ catalog/product/sial $/ 43534$ ?lang $=$ pl\&region $=$ PL. Accessed 25 Jan 2021

236. Krzepiłko A, Prażak R, Skwaryło-Bednarz B, Święciło A (2018) Pąki, liście i nasiona porzeczki czarnej—źródło substancji bioaktywnych o prozdrowotnych właściwościach. Żywność Nauka - Technol - Jakość 115:24-33. https://doi.org/ 10.15193/ZNTJ/2018/115/230

237. Tymchuk I, Kutsyk R, Danylejchenko V, Korniichuk O (2014) Antifungal activity of water-ethanol extracts of medicinal plants on Candida albicans. Acta Med Leopoliensia 20:88-94

238. Popova T, Potanina O (2011) Flavonoids of blackcurrant (Ribes nigrum) leaves and buds. Pharmacy 2:11-13

239. Ethorđević BS, Pljevljakušić ĐS, Savikin KP et al (2014) Essential oil from black currant buds as chemotaxonomy marker and antimicrobial agent. Chem Biodivers 11:1228-1240. https://doi. org/10.1002/cbdv.201400039

240. Kuldyrkaeva K (2009) Ribes nigrum: pharmacognostic description, pharmacological activity, medical application. Ukr J Clin Lab Med 4:15-21

241. Barnes MJ, Perry BG, Hurst RD, Lomiwes D (2020) Anthocyanin-rich New Zealand blackcurrant extract supports the maintenance of forearm blood-flow during prolonged sedentary sitting. Front Nutr 7:74. https://doi.org/10.3389/fnut.2020.00074

242. Manea-Saghin A-M, Tihan GT, Zgarian RG et al (2020) Linear and non-linear optical properties of gelatin membranes doped with photoresponsive berries extracts. Opt Mater 108:110429. https://doi.org/10.1016/j.optmat.2020.110429

243. Enache IM, Vasile AM, Enachi E et al (2020) Co-microencapsulation of anthocyanins from black currant extract and lactic acid bacteria in biopolymeric matrices. Molecules 25:1700. https:// doi.org/10.3390/molecules 25071700

244. Wu G, Hui X, Stipkovits L et al (2021) Whey protein-blackcurrant concentrate particles obtained by spray-drying and freezedrying for delivering structural and health benefits of cookies. Innov Food Sci Emerg Technol 68:102606. https://doi.org/10. 1016/j.ifset.2021.102606

245. Mu J, Wu G, Chen Z et al (2021) The effects of blackcurrant and strawberry powder on the physicochemical and in vitro glycaemic response of starches derived from sweet potato (Ipomoea batatas) and potato (Solanum tuberosum). Int J Food Sci Technol. https://doi.org/10.1111/ijfs.15272

246. Lee W-G (2018) Quality characteristic and antioxidant properties of gelatin jelly incorporated with black currant (Ribes nigrum L.) powder. Culin Sci Hosp Res 24:113-120. https://doi.org/10. 20878/cshr.2018.24.3.011

247. Robles H (2014) Tannic acid. In: Wexler P (ed) Encyclopedia of toxicology, 3rd edn. Academic Press, Oxford, pp 474-475

248. Bilek M, Kozlowska-Tylingo K, Gostkowski M, Staniszewski P (2019) Gall-nuts of native oak species as a potential tannin raw material. Sylwan 163:746-753. https://doi.org/10.26202/sylwan. 2019017

249. Giertych M, Pilichowski S (2018) Gall abundance and leaf size as factors affecting the hypersensitive reaction in the common beech (Fagus sylvatica). Balt For 23:608-611

250. Mani MS (1964) Ecology of plant galls. Springer Netherlands, The Hague

251. Golonko A, Świsłocka R, Kalinowska M, Lewandowski W (2019) Tannic acid - a pro-health or anti-nutritional compound? Postępy Nauki Technol Przem Rolno-Spoż 74:89-101

252. Ahmad N, Alam M, Naushad M et al (2018) Thermal decomposition and kinetic studies of tannic acid using model free-methods.
J Chil Chem Soc 63:3824-3828. https://doi.org/10.4067/s071797072018000103824

253. Allais M, Mailley D, Hébraud P et al (2018) Polymer-free electrospinning of tannic acid and cross-linking in water for hybrid supramolecular nanofibres. Nanoscale 10:9164-9173. https://doi. org/10.1039/C8NR01067F

254. Sahiner N, Sagbas S, Sahiner M et al (2016) Biocompatible and biodegradable poly(tannic acid) hydrogel with antimicrobial and antioxidant properties. Int J Biol Macromol 82:150-159. https:// doi.org/10.1016/j.ijbiomac.2015.10.057

255. Kim TJ, Silva JL, Kim MK, Jung YS (2010) Enhanced antioxidant capacity and antimicrobial activity of tannic acid by thermal processing. Food Chem 118:740-746. https://doi.org/10.1016/j. foodchem.2009.05.060

256. Pyla R, Kim T-J, Silva JL, Jung Y-S (2010) Enhanced antimicrobial activity of starch-based film impregnated with thermally processed tannic acid, a strong antioxidant. Int J Food Microbiol 137:154-160. https://doi.org/10.1016/j.ijfoodmicro.2009.12.011

257. Nadolna K, Kaczmarek B, Owczarek A, Sionkowska A (2019) Ogólnopolska Konferencja Naukowa "Chemia dla urody"księga abstraktów. In: Właściwości materiałów na bazie chitozanu i kwasu taninowego-badania biologiczne. Wydawnictwo Wyższej Szkoły Inżynierii i Zdrowia w Warszawie, Warszawa, pp 31-32

258. Owczarek A (2019) Ogólnopolska Konferencja Naukowa "Chemia dla urody"-księga abstraktów. In: Nowe matryce na bazie alginianu sodu oraz kwasu taninowego. Wydawnictwo Wyższej Szkoły Inżynierii i Zdrowia w Warszawie, Warszawa, pp 33-34

259. Ge W, Cao S, Shen F et al (2019) Rapid self-healing, stretchable, moldable, antioxidant and antibacterial tannic acid-cellulose nanofibril composite hydrogels. Carbohydr Polym 224:1-9. https://doi.org/10.1016/j.carbpol.2019.115147

260. Sun C, Yu M, Zeng Z et al (2020) Biocidal activity of polylactic acid-based nano-formulated abamectin on Acyrthosiphon pisum (Hemiptera: Aphididae) and the aphid predator Adalia bipunctata (Coleoptera: Coccinellidae). PLoS ONE 15:1-11. https://doi.org/ 10.1371/journal.pone.0228817

261. Biegaj M (2016) Acne vulgaris and its treatment. Kosmetol Estet 6:155-158

262. Hu S, Wang T, Fernandez ML, Luo Y (2016) Development of tannic acid cross-linked hollow zein nanoparticles as potential oral delivery vehicles for curcumin. Food Hydrocoll 61:821-831. https://doi.org/10.1016/j.foodhyd.2016.07.006

263. Zhang Z-Q, Pan C-H, Chung D (2011) Tannic acid cross-linked gelatin-gum arabic coacervate microspheres for sustained release of allyl isothiocyanate: characterization and in vitro release study. Food Res Int 44:1000-1007. https://doi.org/10.1016/j.foodres. 2011.02.044

264. Park K, Jeong H, Tanum J et al (2019) Developing regulatory property of gelatin-tannic acid multilayer films for coating-based nitric oxide gas delivery system. Sci Rep 9:8308. https://doi.org/ 10.1038/s41598-019-44678-2

265. Yang S, Zhang Y, Wang T et al (2020) Ultrafast and programmable shape memory hydrogel of gelatin soaked in tannic acid solution. ACS Appl Mater Interfaces 12:46701-46709. https:// doi.org/10.1021/acsami.0c13531

266. Xu F, Weng B, Gilkerson R et al (2015) Development of tannic acid/chitosan/pullulan composite nanofibers from aqueous solution for potential applications as wound dressing. Carbohydr Polym 115:16-24. https://doi.org/10.1016/j.carbpol.2014.08.081

267. Zou Y, Guo J, Yin S-W et al (2015) Pickering emulsion gels prepared by hydrogen-bonded zein/tannic acid complex colloidal particles. ACS Publications. https://pubs.acs.org/doi/abs/10. 1021/acs.jafc.5b03113. Accessed 2 Oct 2021 
268. Zou Y, Yang X, Scholten E (2018) Rheological behavior of emulsion gels stabilized by zein/tannic acid complex particles. Food Hydrocoll 77:363-371. https://doi.org/10.1016/j.foodhyd.2017. 10.013

269. Santos TM, Souza Filho M de SM, Silva E de O et al (2018) Enhancing storage stability of guava with tannic acid-crosslinked zein coatings. Food Chem 257:252-258. https://doi.org/10. 1016/j.foodchem.2018.03.021

270. Huang D, Zhang Z, Quan Q, Zheng Y (2020) Tannic acid: a versatile and effective modifier for gelatin/zein composite films. Food Packag Shelf Life 23:100440. https://doi.org/10.1016/j.fpsl. 2019.100440

271. Menezes M do LLR, Pires N da R, da Cunha PLR et al (2019) Effect of tannic acid as crosslinking agent on fish skin gelatinsilver nanocomposite film. Food Packag Shelf Life 19:7-15. https://doi.org/10.1016/j.fpsl.2018.11.005

272. Halim ALA, Kamari A, Phillip E (2018) Chitosan, gelatin and methylcellulose films incorporated with tannic acid for food packaging. Int J Biol Macromol 120:1119-1126. https://doi.org/ 10.1016/j.ijbiomac.2018.08.169

273. Lin H, Pei L, Zhang L (2018) Enhanced thermal conductivity of PLA-based nanocomposites by incorporation of graphite nanoplatelets functionalized by tannic acid. J Appl Polym Sci 135:46397. https://doi.org/10.1002/app.46397

274. Liu W, Qiu J, Chen T et al (2019) Regulating tannic acidcrosslinked epoxidized soybean oil oligomers for strengthening and toughening bamboo fibers-reinforced poly(lactic acid) biocomposites. Compos Sci Technol 181:107709. https://doi.org/ 10.1016/j.compscitech.2019.107709

275. Jin X, Xiang E, Zhang R et al (2021) Halloysite nanotubes immobilized by chitosan/tannic acid complex as a green flame retardant for bamboo fiber/poly(lactic acid) composites. J Appl Polym Sci 138:49621. https://doi.org/10.1002/app.49621

276. Krasutsky P (2007) Birch bark research and development. Nat Prod Rep 23:919-942. https://doi.org/10.1039/b606816b

277. Pezzuto JM, Kim DSHL (1998) Methods of manufacturing betulinic acid, US5804575A. https://patents.google.com/patent/ US5804575A/en. Accessed 24 Jun 2021

278. Tolstikov G, Flekhter O, Shultz E et al (2005) Betulin and its derivatives. Chemistry and biological activity. Chem Sustain Dev 13:1-29

279. Kujawa-Warchala K, Nazaruk J (2011) Pharmacological activity of pentacyclic triterpene compounds. Postępy Fitoterapii 1:35-47

280. Kim DSHL, Chen Z, van Nguyen T et al (1997) A concise semisynthetic approach to betulinic acid from betulin. Synth Commun 27:1607-1612. https://doi.org/10.1080/00397919708006099

281. Lowitz JT (1790) Materia alba in epidermide betulae albae, recens detecta et examini chemico subiecta. Nova Acta Acad Sci Imp Petropolitanae 6:48-56

282. Amiri S, Dastghaib S, Ahmadi M et al (2020) Betulin and its derivatives as novel compounds with different pharmacological effects. Biotechnol Adv 38:1-39. https://doi.org/10.1016/j.biote chadv.2019.06.008

283. Jonnalagadda SC, Suman P, Morgan DC, Seay JN (2017) Chapter 2-recent developments on the synthesis and applications of betulin and betulinic acid derivatives as therapeutic agents. In: Atta-ur-Rahman (ed) Studies in natural products chemistry. Elsevier, Amsterdam, pp 45-84

284. Pavlova NI, Savinova OV, Nikolaeva SN et al (2003) Antiviral activity of betulin, betulinic and betulonic acids against some enveloped and non-enveloped viruses. Fitoterapia 74:489-492. https://doi.org/10.1016/S0367-326X(03)00123-0

285. Baltina L, Flekhter OB, Nigmatullina LR et al (2003) Lupane triterpenes and derivatives with antiviral activity. Bioorg Med Chem Lett 13:3549-3552. https://doi.org/10.1016/S0960894X(03)00714-5
286. Yu H, Zhang H, Chu Z et al (2017) Combination of betulinic acid and chidamide synergistically inhibits Epstein-Barr virus replication through over-generation of reactive oxygen species. Oncotarget 8:61646-61661. https://doi.org/10.18632/oncotarget. 18661

287. Bedoya LM, Beltrán M, García-Pérez J et al (2018) Promiscuous, multi-target lupane-type triterpenoids inhibits wild type and drug resistant HIV-1 replication through the interference with several targets. Front Pharmacol 9:1-16. https://doi.org/10.3389/fphar. 2018.00358

288. Dang Z, Ho P, Zhu L et al (2013) New betulinic acid derivatives for bevirimat-resistant human immunodeficiency virus type-1. J Med Chem 56:2029-2037. https://doi.org/10.1021/jm3016969

289. Haque S, Nawrot DA, Alakurtti S et al (2014) Screening and characterisation of antimicrobial properties of semisynthetic betulin derivatives. PLoS ONE 9:1-9. https://doi.org/10.1371/ journal.pone.0102696

290. Oloyede HOB, Ajiboye HO, Salawu MO, Ajiboye TO (2017) Influence of oxidative stress on the antibacterial activity of betulin, betulinic acid and ursolic acid. Microb Pathog 111:338-344. https://doi.org/10.1016/j.micpath.2017.08.012

291. Denisov MS, Beloglazova YA (2020) Anticoronaviral activity of triterpenoids. Biomed Chem Res Methods 3:1-8. https://doi.org/ 10.18097/BMCRM00127

292. Swinarew A, Boryczka S, Mazurek U et al (2020) Modified thermoplastic polymer with antibacterial and anti-inflammatory properties and method for obtaining it, P.422092. https:// ewyszukiwarka.pue.uprp.gov.pl/search/pwp-details/P.422092. Accessed 7 Oct 2021

293. Zadeh Mehrizi T, Khamesipour A, Shafiee Ardestani M et al (2019) Comparative analysis between four model nanoformulations of amphotericin B-chitosan, amphotericin B-dendrimer, betulinic acid-chitosan and betulinic acid-dendrimer for treatment of Leishmania major: real-time PCR assay plus. Int $\mathbf{J}$ Nanomed 14:7593-7607. https://doi.org/10.2147/IJN.S220410

294. Zadeh Mehrizi T, Shafiee Ardestani M, Haji Molla Hoseini M et al (2018) Novel nanosized chitosan-betulinic acid against resistant leishmania major and first clinical observation of such parasite in kidney. Sci Rep 8:11759. https://doi.org/10.1038/ s41598-018-30103-7

295. Hussein-Al-Ali SH, Arulselvan P, Fakurazi S, Hussein MZ (2014) The in vitro therapeutic activity of betulinic acid nanocomposite on breast cancer cells (MCF-7) and normal fibroblast cell (3T3). J Mater Sci 49:8171-8182. https://doi.org/10.1007/ s10853-014-8526-3

296. Tan JM, Karthivashan G, Abd Gani S et al (2016) Biocompatible polymers coated on carboxylated nanotubes functionalized with betulinic acid for effective drug delivery. J Mater Sci Mater Med 27:26. https://doi.org/10.1007/s10856-015-5635-8

297. Tan JM, Bullo S, Fakurazi S, Hussein MZ (2021) Characterization of betulinic acid-multiwalled carbon nanotubes modified with hydrophilic biopolymer for improved biocompatibility on NIH/3T3 cell line. Polymers 13:1362. https://doi.org/10.3390/ polym 13091362

298. Lu S, Fan X, Wang H et al (2020) Synthesis of gelatin-based dual-targeted nanoparticles of betulinic acid for antitumor therapy. ACS Appl Bio Mater 3:3518-3525. https://doi.org/10.1021/ acsabm.9b01204

299. Saneja A, Kumar R, Singh A et al (2017) Development and evaluation of long-circulating nanoparticles loaded with betulinic acid for improved anti-tumor efficacy. Int J Pharm 531:153-166. https://doi.org/10.1016/j.ijpharm.2017.08.076

300. Gómez Castellanos JR, Prieto JM, Heinrich M (2009) Red Lapacho (Tabebuia impetiginosa) — a global ethnopharmacological commodity? J Ethnopharmacol 121:1-13. https://doi.org/10. 1016/j.jep.2008.10.004 
301. Hussain H, Krohn K, Ahmad V et al (2007) Lapachol: an overview. Ark Arch Org Chem 2:145-171

302. Epifano F, Genovese S, Fiorito S et al (2014) Lapachol and its congeners as anticancer agents: a review. Phytochem Rev 13:3749. https://doi.org/10.1007/s11101-013-9289-1

303. Paradowska K, Wawer I (2015) Peruvian herbs in Europe. Herbalism 1:20-38. https://doi.org/10.12775/HERB.2015.002

304. Bołonkowska O, Pietrosiuk AI, Sykłowska-Baranek K (2011) Roślinne związki barwne ich właściwości biologiczne oraz możliwości wytwarzania w kulturach in vitro. Biul Wydz Farm Warsz Uniw Med 1:1-27

305. Paterno E (1882) Ricerche sull'acido lapachico. Gazzetta Chim Ital 12:337-392

306. Hussain H, Green IR (2017) Lapachol and lapachone analogs: a journey of two decades of patent research (1997-2016). Expert Opin Ther Pat 27:1111-1121. https://doi.org/10.1080/13543776. 2017.1339792

307. Fitoncydy - Encyklopedia PWN. https://encyklopedia.pwn.pl/ haslo/fitoncydy;3901302.html. Accessed 5 Jan 2021

308. Ventura Pinto A, Lisboa de Castro S (2009) The trypanocidal sctivity of naphthoquinones: a review. Molecules 14:4570-4590. https://doi.org/10.3390/molecules 14114570

309. Gómez OC, Luiz JHH (2018) Endophytic fungi isolated from medicinal plants: future prospects of bioactive natural products from Tabebuia/Handroanthus endophytes. Appl Microbiol Biotechnol 102:9105-9119. https://doi.org/10.1007/ s00253-018-9344-3

310. Stepczyńska M, Rytlewski P (2018) Enzymatic degradation of flax-fibers reinforced polylactide. Int Biodeterior Biodegrad 126:160-166. https://doi.org/10.1016/j.ibiod.2017.11.001

311. Stepczyńska M, Pawłowska A, Moraczewski K et al (2021) Evaluation of the mechanical and biocidal properties of lapacho from Tabebuia plant as a biocomposite material. Materials 14:1-16. https://doi.org/10.3390/ma14154241

312. de Miranda PRB, Silva TS, de Abreu FC et al (2014) Thermodynamic parameters of the interactions between lapachol and isolapachol sodium salts and chitosan flakes. J Chem Eng Data 59:1181-1192. https://doi.org/10.1021/je400725n

313. Longuinho MM, Leitão SG, Silva RSF et al (2019) Lapazine loaded alginate/chitosan microparticles: enhancement of antimycobacterium activity. J Drug Deliv Sci Technol 54:101292. https://doi.org/10.1016/j.jddst.2019.101292

314. Oliveira MEFAG, Silva ÉCGM, Câmara CA et al (2018) Evaluation of acute toxicity of $\beta$-lapachone associated with chitosan as a cytoprotective agent. J Bras Patol E 54:279-287. https://doi. org/10.5935/1676-2444.20180048

315. Pereira SA, dos Santos SBF, Rodrigues FAM et al (2020) Hydroxyethyl starch nanocapsules by multiple nanoemulsions for carrying and controlled release of lapachol. Mater Lett 274:127983. https://doi.org/10.1016/j.matlet.2020.127983

316. Kulczyński B, Gramza-Michałowska A (2016) The importance of selected spices in cardiovascular diseases. Adv Hyg Exp Med 70:1131-1141

317. Kania-Dobrowolska M, Baraniak J, Górska A et al (2020) Ginger and garlic - herbal materials that lower cholesterol and glucose. Postępy Fitoter 3:169-176

318. Marchese A, Barbieri R, Sanches-Silva A et al (2016) Antifungal and antibacterial activities of allicin: a review. Trends Food Sci Technol 52:49-56. https://doi.org/10.1016/j.tifs.2016.03.010

319. Salehi B, Zucca P, Orhan IE et al (2019) Allicin and health: a comprehensive review. Trends Food Sci Technol 86:502-516. https://doi.org/10.1016/j.tifs.2019.03.003

320. Pangastuti A, Indriwati SE, Amin M (2018) Investigation of the anti-aging properties of allicin from Allium sativum L. bulb extracts by a reverse docking approach. Trop J Pharm Res 17:635-639. https://doi.org/10.4314/tjpr.v17i4.10
321. Rodriguez E, Gonzalez-Rodriguez J, Valladarez-Cisneros MG et al (2017) Experimental and theoretical evaluation of allicin as corrosion Inhibitor for carbon steel in sulfuric acid. J Mater Environ Sci 8:2028-2508

322. Ankri S, Mirelman D (1999) Antimicrobial properties of allicin from garlic. Microbes Infect 1:125-129. https://doi.org/10.1016/ s1286-4579(99)80003-3

323. Loi VV, Huyen NTT, Busche T et al (2019) Staphylococcus aureus responds to allicin by global S-thioallylation-role of the Brx/BSH/YpdA pathway and the disulfide reductase MerA to overcome allicin stress. Free Radic Biol Med 139:55-69. https:// doi.org/10.1016/j.freeradbiomed.2019.05.018

324. Karasjova NJU, Belova TA (2019) Sovremennaja paradigma estestvennykh i tekhnicheskikh nauk. In: Fungicidnye i fitocidnye svojjstva biologicheski aktivnykh veshhestv fitogennogo proiskhozhdenija. Obshhestvo s ogranichennojj otvetstvennostju "Agentstvo perspektivnykh nauchnykh issledovanijj, Belgorod, pp 43-46

325. Książek E, Grochowalska A, Krauss H, Chęcińska-Maciejewska Z (2016) Natural immune response modifiers. Probl Hig Epidemiol 97:297-307

326. Jebali A, Hekmatimoghaddam S, Behzadi A et al (2013) Antimicrobial activity of nanocellulose conjugated with allicin and lysozyme. Cellulose 20:2897-2907. https://doi.org/10.1007/ s10570-013-0084-3

327. Wang Y-F, Shao J-J, Wang Z-L, Lu Z-X (2012) Study of allicin microcapsules in $\beta$-cyclodextrin and porous starch mixture. Food Res Int 49:641-647. https://doi.org/10.1016/j.foodres.2012.09. 033

328. Pirak T, Jangchud A, Jantawat $P$ (2012) Characterisation of physical, chemical and antimicrobial properties of allicin-chitosan complexes. Int J Food Sci Technol 47:1339-1347. https://doi. org/10.1111/j.1365-2621.2012.02978.x

329. Li T, Jiang Y, Li J, Hu W (2017) An investigation on quality of Japanese sea bass (Lateolabrax japonicas) using chitosan assisted with origanum vulgare oil and allicin. J Food Process Preserv 41:e12918. https://doi.org/10.1111/jfpp.12918

330. Ren YF, Wang SM, He JY, Fang LC (2009) Effect of the complex coating of chitosan and allicin on fresh-keeping of grape. Guizhou Agric Sci 12:177-179

331. Ee Huey C, Zaireen Nisa Yahya W, Mansor N (2019) Allicin incorporation as urease inhibitor in a chitosan/starch based biopolymer for fertilizer application. Mater Today Proc 16:21872196. https://doi.org/10.1016/j.matpr.2019.06.109

332. Ossama M, Hathout RM, Attia DA, Mortada ND (2019) Enhanced allicin cytotoxicity on hepg-2 cells using glycyrrhetinic acid surface-decorated gelatin nanoparticles. ACS Omega 4:11293-11300. https://doi.org/10.1021/acsomega.9b01580

333. Liu Y, Song R, Zhang X, Zhang D (2020) Enhanced antimicrobial activity and $\mathrm{pH}$-responsive sustained release of chitosan/ poly(vinyl alcohol)/graphene oxide nanofibrous membrane loading with allicin. Int J Biol Macromol 161:1405-1413. https://doi. org/10.1016/j.ijbiomac.2020.08.051

334. Chen W, Li X, Zeng L et al (2021) Allicin-loaded chitosan/polyvinyl alcohol scaffolds as a potential wound dressing material to treat diabetic wounds: an in vitro and in vivo study. J Drug Deliv Sci Technol 65:102734. https://doi.org/10.1016/j.jddst.2021. 102734

335. Olejnik O, Masek A, Kiersnowski A (2020) Thermal analysis of aliphatic polyester blends with natural antioxidants. Polymers 12:74. https://doi.org/10.3390/polym12010074

336. Rubini K, Boanini E, Menichetti A et al (2020) Quercetin loaded gelatin films with modulated release and tailored anti-oxidant, mechanical and swelling properties. Food Hydrocoll 109:106089. https://doi.org/10.1016/j.foodhyd.2020.106089 
337. Dintcheva RANT (2017) Natural anti-oxidants for bio-polymeric materials. Arch Chem Res. https://doi.org/10.21767/2572-4657. 100013

338. Tavassoli M, Sani MA, Khezerlou A et al (2021) Multifunctional nanocomposite active packaging materials: immobilization of quercetin, lactoferrin, and chitosan nanofiber particles in gelatin films. Food Hydrocoll 118:106747. https://doi.org/10.1016/j. foodhyd.2021.106747

339. Zhang X, Do MD, Casey P et al (2010) Chemical modification of gelatin by a natural phenolic cross-linker, tannic acid. J Agric Food Chem 58:6809-6815. https://doi.org/10.1021/jf1004226
340. Rivero S, García MA, Pinotti A (2010) Crosslinking capacity of tannic acid in plasticized chitosan films. Carbohydr Polym 82:270-276. https://doi.org/10.1016/j.carbpol.2010.04.048

341. Mvango S, Mthimkhulu N, Fru PN et al (2020) Physico-chemical characterization of polyethylene glycol-conjugated betulinic acid. AIP Conf Proc 2289:020039. https://doi.org/10.1063/5.0028479

Publisher's Note Springer Nature remains neutral with regard to jurisdictional claims in published maps and institutional affiliations. 